\title{
Kargabedir Tepe (Ankara-Eskişehir Karayolu) Bölgesinin Kaya Düşmesi Duyarlılığının İnsansız Hava Aracı (İHA) Görüntüleri Kullanılarak Konik Yayılım Yaklaşımıyla Değerlendirilmesi
}

\author{
Evaluation of Rockfall Susceptibility of Kargabedir Tepe (Ankara-Eskişehir Highway) \\ Region by Cone Propagation Approach Using Unmanned Aerial Vehicle (UAV) Images
}

\author{
Aycan KALENDER* D, Harun SÖNMEZ D
}

Hacettepe Üniversitesi, Jeoloji Mühendisliği Bölümü, Uygulamalı Jeoloji Anabilim Dalı, 06800 Beytepe Ankara Jeoloji Mühendisliği Bölümü, Ankara

Geliş (Received): 02 Temmuz (July) 2019 / Düzeltme (Revised): 01 Ağustos (August) 2019 / Kabul (Accepted): 15 Ağustos (August) 2019

\section{ÖZ}

Kaya düşmesi olayı Varnes (1978) tarafından, dik yamaçlardaki eklemli kaya kütlelerinden serbestleşen kaya bloklarının eğim aşağı yüksek hızda hareket ettiği bir duraysızlık türü olarak tanımlanmaktadır. Kaynak bölgesindeki kaya bloğu serbest kaldığı noktadan itibaren bir yörünge boyunca enerjisi sönümlenip durana kadar hareketine eğim aşağ 1 devam eder. Deterministik yaklaşımlarda gerek yamaç yüzeyine ve gerekse bloğa ait çok sayıda fiziksel ve mekanik parametre girdi olarak kullanılmakta olup, bu nedenle sonuçların gerçekçiliği de bu fazla sayıdaki girdi parametresiyle yakın ilişkilidir. Bunun bir yansıması olarak özellikle bölgesel ölçekte kaya düşmesi haritalarının hazırlanmasında pratik değeri oldukça yüksek olan ampirik yaklaşımlar tercih edilmektedir. Bu ampirik yaklaşımlardan Jabodeyoff ve Labiouse (2011) tarafından önerilen konik yayılım yaklaşımı sadece kaynak alan haritası ve sayısal yükseklik modelini (SYM) girdi parametresi olarak kullanması sebebiyle oldukça pratik olup, büyük alanların bölgesel olarak kaya düşmesi açısından değerlendirilmesinde öne çıkmaktadır. Bu çalışmada, SYM üzerinde olası yayılım zonunun belirlenmesi ilkesini temel alan bu yöntemin sinanması amacıyla Kargabedir Tepe kaya düşmesi bölgesinde çeşitli saha çalışmaları geçekleştirilmiştir. Kargabedir Tepe'deki saha çalışmaları kapsamında inceleme alanının yüksek çözünürlüklü SYM'nin elde edilmesi amacıyla bir dron (insansız hava aracı -IHHA) kullanılarak bölgenin yüksek çözünürlüklü hava fotoğrafları alınmıştır. Bölgeye ait 40x40 cm çözünürlüğe sahip bir sayısal yükseklik modeli ve $5 \times 5 \mathrm{~cm}$ çözünürlüklü ortorektifiye hava fotoğrafı oluşturulmuştur. Çalışma sahasına ait SYM kullanılarak konik yayılım yaklaşımıyla farklı enerji çizgi açısı değerleri için yayılım zonu haritaları üretilmiş̧ir. Ayrıca bölgedeki mevcut düşmüş bloklarının konumları belirlenmiş ve en-boy-yükseklikleri ölçülmüştür. Buna ek olarak düşen kaya bloklarının boyutları ve konumları ortorektifiye fotoğrafı üzerinde de belirlenmiş ve sahada yapılan ölçümlerle uyumlulukları sınanmıştır. Saha ve ortorektifiye fotoğraftan elde edilen bloklara ilişkin en-boy-yükseklik ölçümlerinin birbirleriyle uyumlu olduğu sonucuna varılmıştır.

Anahtar kelimeler: Kaya düşmesi, Konik Yayılım Yaklaşımı, İnsansız Hava Aracı (İha), Sayısal Yükseklik Modeli (SYM), Ortorektifiye Fotoğraf 
Kalender, Sönmez

\begin{abstract}
Rockfall is defined by Varnes (1978) as a type of instability in which rock blocks released from rock masses on steep slopes and move at high speed down along the slope. The rock block releases from the source point moves downward along a trajectory until its energy is extinguished. In deterministic approaches, a large number of physical and mechanical parameters of both slope surface and block, are used as inputs, and therefore the results are closely related to accuracy of this number of input parameters. As a reflection of this, empirical approaches, which have a very high practical value, are preferred especially in the preparation of rockfall maps on regional scale. The cone propagation approach proposed by Jabodeyoff and Labiouse (2011) is a practical method for regional scale and stands out among other empirical approaches due to uses only source area map and digital elevation model (DEM) as input parameters. In this study, in order to test this method various field studies were carried out in Kargabedir rockfall area based on the principle of determination of possible propagation zone on DEM. In the field studies carried out at Kargabedir Hill, high resolution aerial photos of the region were taken using a Dron (unmanned aerial vehicle-UAV) to obtain a high resolution DEM. Thus, a high-resolution $(40 \mathrm{~cm} /$ pixel) DEM and a very high resolution (5 cm/pixel) orthorectified aerial image were generated for the area. Propagation zone maps of Kargabedir rockfall area were prepared for different energy line angle values using high-resolution DEM with cone propagation approach. In addition, the positions and dimensions (height/length/width) of the fallen blocks were measured in the region. The dimensions and positions of the fallen blocks were also determined from the orthophoto and their compatibility with the site measurements was examined. It has been observed that width-length-height measurements of the fallen blocks acquired from the field and orthophoto are compatible.
\end{abstract}

Key words: Rockfall, Cone Propagation Approach, Unmanned Aerial Vehicle (UAV), Digital Elevation Model (DEM), Orthorectified Aerial Image

\section{GİRis}

Kaya düşmelerinin ani olarak gelişmeleri ve hızlı yayılım göstermeleri nedeniyle karayolları, demiryolları ve yamaç bölgelerindeki yerleşim alanlarında büyük tehlikelere yol açabilmektedir. Kaya düşmeleri dik yamaçlarda yüzeylenen kaya kütlelerindeki bloklara etki eden çeşitli iklimsel ve biyolojik etkiler veya deprem gibi kuvvetlerle bloğun dengesinde değişime sebep olan tetikleyiciler tarafindan başlatılır (Kalender, 2017). Kaya bloğunun yerinde durağan haldeki potansiyel enerjisi öncelikle eğim aşağı hareketle birlikte kinetik enerjiye dönüşürken, diğer taraftan da yüzey ile temas ettiği bölgelerde ise çarpma, sürtünme ve yuvarlanma sonucunda enerji kayıplarıla hareketine devam eder ve tüm enerjisi sönümlenince kaya bloğu durur. $\mathrm{Bu}$ yönüyle bakıldığında kaya düşmesi olayının mekanizması bilinen temel fizik prensiplerine dayanmaktadır (Şekil 1). Düşen kaya bloğunun yüzey teması sırasında olası parçalanması durumunun gerçekçi bir şekilde deterministik analizlerle yansitılabilmesi tam olarak mümkün olamamaktadır. Bununla birlikte, 3-D (üç boyutlu) ayrık eleman analizleriyle kaya düşmesi ve kaya çığları sırasında kaya bloklarının parçalanmasının araştırılmasına yönelik Zhao vd. (2017) tarafindan yapılan çalışmada olduğu gibi düşen kaya bloklarının parçalanması ve eğim aşağı yüzeyde dağılımlarının belirlenmesine yönelik yeni yöntemsel yaklaşımlar kaya düşmesi haritalama çalışmalarına katkı sağlayabilecek niteliktedir. 


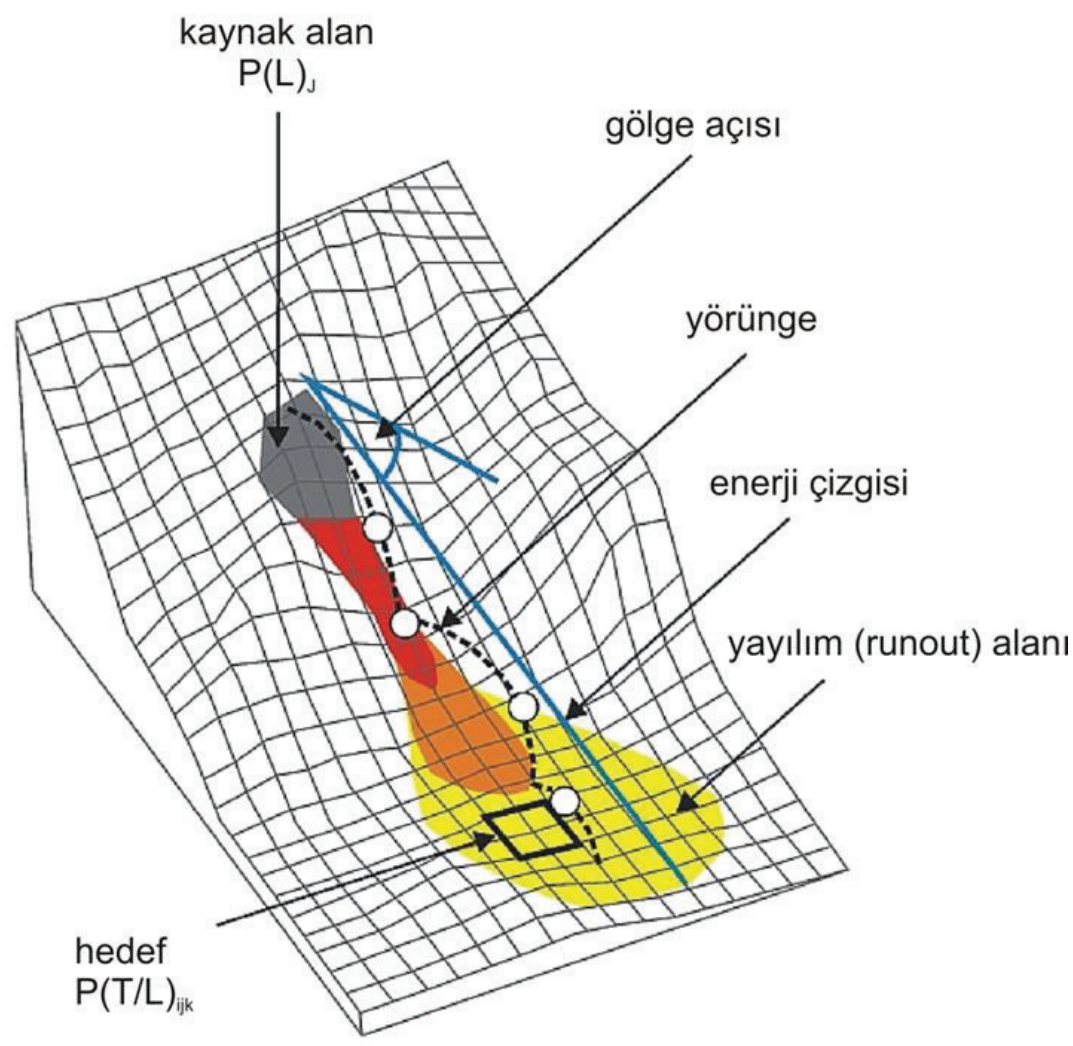

Şekil 1 . Kaya düşmesi tanımlamaları ve ilgili parametreler (Volkwein vd., 2011).

Figure 1. Definition of rockfall and related parameters (Volkwein et al., 2011).

Kaya bloğunun serbest kaldığı nokta ile durma noktasina kadar uzanan mesafe "menzil mesafesi” (ulaşabileceği en uzak mesafe) olarak tanımlanmaktadır (Kalender, 2017). Düşen kaya bloğu yörüngesi boyunca kayma (sliding/toppling), serbest düşme (fall), sıçrama (bouncing/impact) ve yuvarlanma (rolling) olmak üzere dört temel süreç geçirir (Broili, 1973). Serbest düşme ile başlayan harekette bloğun yamaç yüzeyine çarpmasıyla meydana gelen sıçrama hareketi yamaç eğiminin $70^{\circ}$ 'den düşük olduğu durumlarda gerçekleşen harekettir. İlk çarpma sırasında blokta kırılma ve parçalanmalar meydana gelebilir. Herhangi bir kırılma gerçekleşmese de düşen blok düşme sırasında kazandığ enerjinin \%75 ila \%86'sını çarpmayla kaybeder (Broili, 1973; Bozzolo ve Pamnini, 1986; Evans ve Hungr, 1993). $\mathrm{Bu}$ nedenle sıçrama hareketinde (çarpmanın etkisiyle) çarptığı yüzeyin özellikleri ve yüzeyin yönelimine bağlı olarak kaya bloğunun hareket yönelimi ve enerjisi değişkendir. $\mathrm{Bu}$ nedenle sıçrama olayının gerçekleştiği evre konuya ilişkin literatürde kaya düşmesinin en karmaşık ve belirsiz evresi olarak tanımlanmaktadır (Broili, 1973; Bozzolo ve Pamnini, 1986; Azzoni, 1995). Dolayısıyla blok hareketinin türünü belirleyen en önemli etken yamaç geometrisi ve sürecin üzerinde geliştiği yüzeyin özellikleridir. Deterministik analiz modellerinde 
bloğun sıçrama hareketini kontrol eden en kritik parametre "geri sıçrama katsayısı"dır (coefficients of restitution). En basit haliyle geri sıçrama katsayısı yamaç yüzeyine çarpan bloğun hızının veya enerjisinin çarpmadan sonraki hız veya enerjiye oranı $\left(\mathrm{R}=\mathrm{V}_{\mathrm{r}} / \mathrm{V}_{\mathrm{i}}\right)$ olarak tanımlanır (Chau vd., 2002). Çarpma noktasında hareketin vektörel yönüne bağl1 olarak teğetsel geri sıçrama katsayısı $\left(\mathrm{R}_{\mathrm{t}}\right)$ ve normal geri sıçrama katsayısı $\left(\mathrm{R}_{\mathrm{n}}\right)$ olmak üzere iki bileşeni vardır (Şekil 2). Normal ve teğetsel geri sıçrama sayılarının seçilmesi için literatürde yüzey özelliklerinne göre çok geniş aralıklara sahip sayısal öneriler bulunmakla birlikte, mümkün olması halinde kaynak bölgeden atılan veya daha önce düşmüş olan kaya bloklarının geriye dönük analizleriyle $R_{n}$ ve $R_{t}$ değerlerinin saha özgü belirlenmesi de dikkate alınabilmektedir (Kalender, 2017).
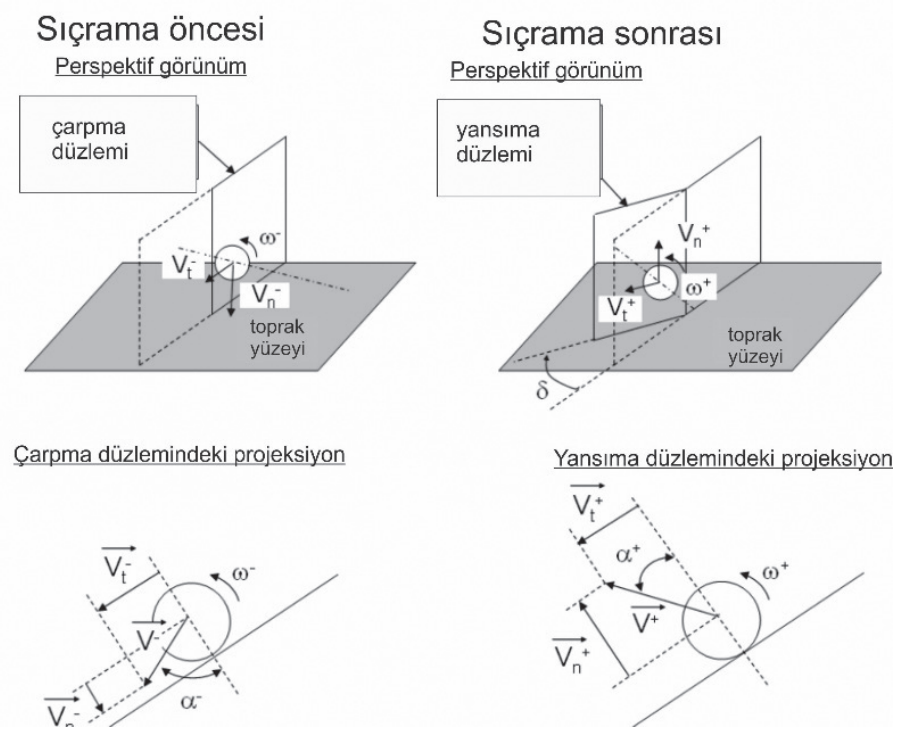

Kaya düşmesi olayının değerlendirilmesine yönelik yaklaşımları deterministik ve olasılıksal (iki 2D veya üç 3D boyutlu) analizler ve ampirik yaklaşımlar olarak iki alt grupta ele almak mümkündür. Kaynak bölgedeki kaya bloğunun potansiyel enerjisinin kinetik enerjiye dönüşümü sırasında sıçrama ve sürüklenme sırasındaki enerji kayıplarıyla durma noktasına kadar kaya bloğunun yörüngesinin temel fizik kurallarıyla şekillenmesi bu analizlerin temelini oluşturmaktadır. Her ne kadar kaya düşmesi mekanizmasının temel fizik prensipleriyle açıklanması mümkün olmasına karşın, bu analizler gerçekte önemli düzeyde bazı belirsizlikler ve sınırlamalar içermektedir. Kaya bloğunun hareketindeki en önemli karmaş1k süreç sıçrama olayı sırasında yaşanmaktadır. Sıçrama hareketi sırasında kaya bloğunun

Şekil 2. Çarpma öncesi ve sonrasında bloğun hız bileşenleri (Volkwein vd., 2011).

Figure 2. Block velocity components before and after rebound (Volkwein et al., 2011). 
çarptığı yüzeyde parçalanması halinde bu durumun analizde dikkate alınması tam olarak mümkün olamamaktadır. $\mathrm{Bu}$ sinırlamanın yanı sıra diğer bir güçlükte bu tür analizlerde bir birbirleriyle etkileşimli çok sayıda girdi parametresinin gerçekçi bir şekilde seçilmesi aşamasında yaşanmaktadır. Kaya düşmesi olayının potansiyel olarak gelişebileceği alanlarda özellikle alanın büyüklügüne ve risk altındaki elemanın özelliklerine bağlı olarak analiz ve değerlendirme yönteminin seçilmesi ön plana çıkar. Deterministik ve olasılıksal analizlerde düşen kaya bloğunun yörüngesinin öngörülebilmesi ve ayrıca, yörünge boyunca hızının ve enerjisinin daha gerçekçi bir şekilde belirlenebilmesi mümkündür ve özellikle önleme yapılarının tasarımında oldukça yararlı bilgiler sunabilmektedir. Buna karşın, uygulama açısından pratik bir ampirik yöntem olan Jabodeyoff ve Labiouse (2011) tarafindan önerilen konik yayılım yaklaşımı (cone propagation) geniş sahaların kaya düşmesine karşı duyarlılıklarının tanımlanması amacıyla yaygın bir şekilde tercih edilmektedir. Konik yayılım yaklaşımı bir kaya düşmesi bölgesindeki potansiyel kaynak alanları ve çıkış bölgelerini tahmin etmeyi mümkün kılar. SYM'den (Sayısal Yükseklik Modeli) oluşturulan eğim haritaları kullanılarak belli bir eğime sahip alanlar potansiyel kaynak alanlar olarak belirlenebilir.

Konik yayılım yaklaşımında SYM'de kaynak alandan düşen kaya bloğunu temsil eden her hücreden başlayan, diğer bir ifade ile tepe (apex) noktası bu hücrede olan ve enerji çizgi açısı veya gölge açısı kavramlarına göre belirlenen $\beta$ açısı ile düşey konumda bir koni çizilir. Bu düşey koninin eğim aşağ1 kesimdeki topoğrafyayla ara kesiti sonucunda elde edilen alan kaya düşmesi yayılım zonu olarak belirlenir (Şekil 3). (a)

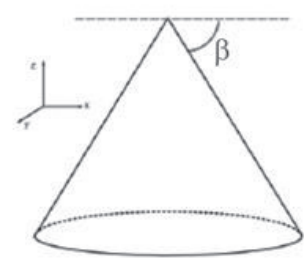

(b)

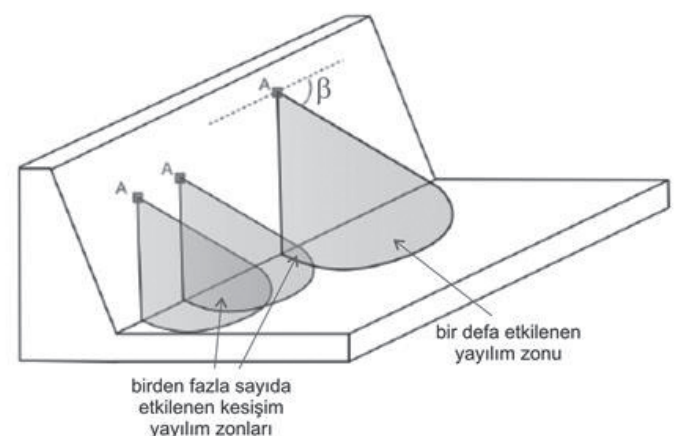

Şekil 3. (a) $\beta$ yayılım açısına sahip yayılım konisi, (b) basitleştirilmiş bir topografya üzerinde bazı yayılma konilerinin kesişimi (Derron vd., 2016).

Figure 3. (a) cone of propagation with an angle of propagation $\beta$; (b) intersection of some propagation cones on a simplified topography. (Derron et al., 2016). 
Jaboyedoff ve Labiouse (2011) tarafindan yazılan ve kullanımı serbest olan CONEFALL yazılımıla, yayılım zonları, hız ve kinetik enerji dağılımı hesaplamalarının yanı sıra yayılım zonundaki her bir hücredeki kaya düşmesinden potansiyel etkilenme sayısı da belirlenebilmektedir. CONEFALL yazılımının çıktı dosyası kullanılarak hazırlanmış kaynak haritası ve sayısal yükseklik modelinin yanı sıra enerji çizgisi açısı, blok kütlesi gibi diğer girdi parametrelerine gereksinim duymaktadır. Çıktı dosyaları ASCI formatında olup, CBS programlariyla kolaylıkla haritaya dönüştürülebilmektedir.

Kaya düşmesi duyarlılık haritalamalarında CBS verilerinin kullanılması pratik ve sık kullanılan bir yöntemdir. Ayrıca, SYM'nin çözünürlüğü arttıkça, oluşturulan eğim haritaları topoğrafyayı daha iyi temsil eder. Ancak, 1/1000 ölçekli topoğrafik haritalara kolaylıkla ulaşılamamasından dolayı bu büyük ölçekli topoğrafik haritalardan yüksek çözünürlüklü bir SYM üretmek her zaman mümkün olmamaktadır. Buna karşın, "Hareketten Yapı-Çok Bakılı Stereofotogrametri” (HY-ÇBS) yöntemi, yüksek çözünürlüklü SYM ve ortorektifiye hava fotoğrafları elde etmek için iyi bir alternatiftir. $\mathrm{Bu}$ çalışmada, pilot bölge olarak seçilen Kargabedir Tepe kaya düşmesi alanının yüksek çözünürlüklü hava fotoğrafları hafif bir İHA (insansız hava arac1) (dron) kullanılarak elde edilmiştir. HYÇBS yöntemi ile bölgenin yüksek çözünürlüklü SYM (0.4 m / piksel) ve çok yüksek çözünürlükte ortorektifiye hava görüntüsü (0.05 m / piksel) oluşturulmuştur. Ayrıca ulaşı1ması güç sahalarda uygulama avantajının sınanması amacıyla düşen kaya bloklarına ilişkin veriler öncelikle sahada doğrudan ölçülmüş ve İHA görüntülerinden elde edilen ortorektifiye hava fotoğrafindan da aynı kaya bloklarının boyutları ölçülerek karşılaştırmaları yapılmıştır. Çalışmanın son aşamasında ise Kargabedir Tepe ve etki alanına yönelik olarak kaya düşmesi duyarlılık haritası da konik yayılım yaklaşımı kullanılarak hazırlanmıştır.

\section{KONIK YAYILIM YAKLAŞIMIYLA KAYNAK ALANLARIN TANIMLANMASI VE MENZIL MESAFELERİNIN (RUN-OUT DISTANCE) BELIRLENMESI}

Kaya düşmesi haritalamalarında ampirik yaklaşım modeli olarak konik yayılım yaklaşımında kaynak alandan serbestleşen kaya bloğu için topoğrafya ve menzil mesafesi arasındaki geometrik ilişki temel alınmaktadır. Bunun için ilk adım kaya bloklarının sertbestleşebileceği kaynak alanların belirlenmesidir. Bölgesel ölçekteki çalışmalarda eğim haritaları kullanılarak belirli bir eğimin üstündeki alanlar potansiyel kaynak alanlar olarak ayırtlanabilmektedir. Diğer bir ifadeyle sayısal yükseklik modelinden (SYM) üretilecek eğim haritalarında belirli bir eğimin üzerindeki alanlar kaya düşmesi açısından potansiyel aktif kaynak alanlar olarak değerlendirilmektedir. $\mathrm{Bu}$ aşamada dikkat edilmesi gereken en önemli durum SYM'in çözünürlügünün artmasıyla eğim haritalarının da gerçek topoğrafyayı temsil edici niteliğinin artmasıdır. $\mathrm{Bu}$ nedenle SYM çözünürlüğünün çalışma alanının büyüklüğüne ve SYM'in hazırlanmasında kullanılacak altlık haritanın ölçeğine de bağlı olarak en fazla $25 \mathrm{~m}$ x 25m olması önerilmektedir. Diğer bir ifadeyle sayısal yükseklik modelinin çözünürlüğü ile aynı lokasyon için hesaplanabilecek eğim değeri yakından ilişkili olup, çözünürlüğün artmasıyla sahadaki gerçek değere daha fazla yaklaşılacağı kuşkusuzdur.

Potansiyel kaynak alanların sınır (en düşük) eğim açısı SYM'nin çözünürlüğe bağlı olarak eşitlik (1)'den belirlenebilmektedir (Troisi vd., 2008; Larcher, 2012'den). 


$$
\propto=55 x R^{-0.075}
$$

Burada, $\alpha$ (derece) potansiyel kaynak alanlar için sınır eğim değerini, RES ise sayısal yükseklik modelinin çözünürlüğünü ifade etmektedir. Örneğin yüksek çözünürlüklü (1x1 m) SYM ile sınır açısı $55^{\circ}$ olarak belirlenirken, çözünürlüğün 25x25 m olması durumunda sınır aç1 $43^{\circ}$ 'ye düşmektedir.

Kaya düşmesi potansiyel kaynak alanları bu basit ampirik yaklaşımla SYM'nin çözünürlüğüne ve varsa serbest düşme yüksekliğine göre ayırtlanabilmektedir. Ancak sadece SYM üzerinde ayırtlanan kaynak alanların potansiyel kaynak alan olduğunun altını çizerek, saha gözlemleri ve/veya hava fotoğrafları ve uydu görüntüleri üzerinde yapılacak çalışmalarla potansiyel kaynak alanların içerisinden kaynak olmayacak alanların çıkarılması kaya düşmesinden etkilenecek sahalara yönelik haritalamaların daha gerçekçi olmasını sağlayacaktır.

$\mathrm{Bu}$ çalışmada çok daha pratik olması ve SYM'nin çözünürlüğüne bağlı olarak eşik bir açı değerinden itibaren potansiyel kaynak alanların belirlendiği çözünürlük-eşik açı değeri ilişkisi kullanılmıştır.

Ritchie (1963) kaya bloğunun menzil mesafesinin kaynak alan (başlama noktası), blok şekli ve geometrisi, yüzey topoğrafyası ve kaya kütlesinin mekanik özellikleri tarafindan kontrol edildiğini belirtmiştir. Düşen kaya bloklarının ulaşabileceği en uzak (menzil) mesafelerin belirlenmesinde dikkate alınan konik yayılım açısı olarak sıklıkla aşağıdaki iki tanım kullanılmaktadır. Her iki tanımın da en önemli avantaj1 menzil mesafelerinin (runout distances) sadece sayısal yükseklik modeli (SYM) kullanılarak Coğrafi Bilgi Sistemleri (CBS) ortamında kolaylıkla belirlenebilmesidir. $\mathrm{Bu}$ çalışmada konik yayılım açısı olarak enerji çizgi açısı kavramı kullanılmıştır.

i. Gölge Açısı (Shadow Angle): kavramında kaya bloğunun kaynak alan içerisinde serbest kaldığ 1 noktanın yerine dik topoğrafyadan serbest düşme ile çarptığı nokta gölge açısının başlangıç noktası olarak dikkate alınır. Kaynak alandan yamaç döküntüsünün tepe noktasına düşen blok, kazandığı kinetik enerjinin büyük bir kısmının bu çarpışma sırasında kaybedecektir. Gölge açısının ilk çarpışmadan sonraki durumu ifade ettiğini ön görerek Evans ve Hungr (2003) tarafindan menzil mesafesinin (run-out distance) belirlenmesinde kullanılabileceği belirtilmiştir.

ii. Ulaşma Açısı (Reach Angle) veya Enerji Çizgi Açısı (Energy Line Angle): Heim (1932) tarafından tanımlanan enerji çizgi açısı literatürde Fahrboschung açısı veya ulaşma açısı (reach angle) (Corominas, 1996) gibi farklı isimlerle de anılmaktadır. Enerji çizgi açısı kaya bloğunun kaynak alanda serbest kaldı ğ nokta ile duracağ1 son nokta arasındaki doğrusal çizginin eğimi ile ifade edilir (Şekil 4). Diğer bir ifadeyle enerji çizgi açısı kavramında, düşen kaya bloğunun yörüngesi boyunca belirli bir açıyla $(\beta=\operatorname{atan}(\mathrm{H} / \mathrm{L}))$ eğim aşağ1 uzatılan doğrunun (enerji çizgisi) topoğrafyayı kestiği nokta menzil mesafesi olarak tanımlanır (Artuç, 2014). 


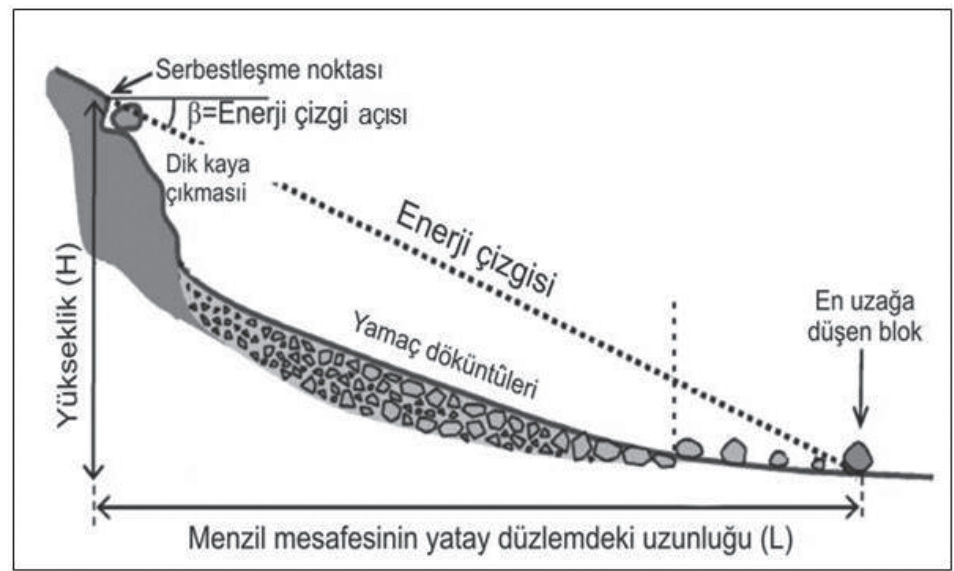

Şekil 4. Enerji çizgi açısı ( $\beta$ ) kavramı (Capons vd., 2009'dan).

Figure 4. Energy line angle ( $\beta$ ) concept (modified after Capons et al., 2009).

Heim (1932) tarafindan önerilen ve uygulama pratiği yüksek olan enerji çizgi açısı kavramına yönelik pek çok araştırmacı farklı sahalarda gözlemler ve ölçümler yapmışlardır. Kaya düşmesi olayında düşen kaya bloğunun belirli bir noktada durması gerçeği nedeniyle farklı sahalarda kaynak noktasından itibaren aşağ 1 uzanan bu açının belirli bir aralıkta değiştiğini belirlemişlerdir(Çizelge 1). Uygulamadaki pratik değeri nedeniyle bu ampirik yaklaşım özellikle bölgesel ölçekteki kaya düşmesi haritalamaları ve değerlendirmelerinde kaya düşmesinin menzil mesafelerinin belirlenmesinde yaygın bir kullanım alanı bulmuştur. Ancak enerji çizgi açısındaki geniş dağılım aralığg kullanımda bir sınırlama yaratmaktadır. Kaya düşmesi olayının doğası gereği, enerji çizgisi açısının değişim aralıkları kaynak alandan eğim aşağı uzanan topoğrafyaya, kaya bloğunun ağırlığına, şekline, jeolojik özelliklere, kaya bloğu ile topoğrafya arasındaki sürtünme direncine, normal ve teğetsel enerji geri sıçrama oranları, eğim aşağ bitki örtüsü ve ağaçlık alanların varlığı gibi çok sayıdaki değişkene bağlıdır. $\mathrm{Bu}$ nedenle, kaya bloklarının menzil mesafesine bağlı olarak tek bir açı değerinin kullanılması yerine kaynak bölgeden eğim aşağıya kaya düşmesi olayından farklı etkilenme derecelerinin ifade edilebildiği kaya düşmesi duyarlılık haritalarının hazırlanması daha fazla tercih edilmektedir. $\mathrm{Bu}$ durumda farklı duyarlılık durumlarına ait enerji açısı değerlerine gereksinim duyulmakta olup, her bir enerji çizgi açısı değeri için konik yayılım yaklaşımının uygulanması gerekmektedir. 
Çizelge 1. Literatürde enerji çizgi açısı için önerilen açı değeri aralıkları (Larcher vd., 2012).

Table 1. Energy line angle range in the literature (Larcher et al., 2012).

\begin{tabular}{|c|c|c|}
\hline \multirow[t]{2}{*}{ Yazar Ad1 ve Yıl1 } & \multicolumn{2}{|c|}{$\begin{array}{l}\text { Enerji çizgi açısı için önerilen açı değerleri } \\
\text { (Parantez içerisindekiler Geometrik Açı) }\end{array}$} \\
\hline & En Düşük Değer Aralığ1 & Ortalama Değer \\
\hline Shreve, 1968 & $\left(26.57^{\circ}-38.66^{\circ}\right)$ & - \\
\hline Onofri ve Candian, 1979 & $\left(28.34^{\circ}-40.73^{\circ}\right)\left(28,84^{\circ}-41,73^{\circ}\right)$ & - \\
\hline Grunder, 1984 & $\left(32.6^{\circ}-33.4^{\circ}\right)\left(33.1^{\circ}-34.4^{\circ}\right)$ & - \\
\hline Domaas, 1985; Toppe, 1987 'den & $32^{\circ}\left(33^{\circ}\right)$ & - \\
\hline Gerber, 1994 & $\left(33^{\circ}-37^{\circ}\right)\left(33.5^{\circ}-38^{\circ}\right)$ & - \\
\hline Meissl, 1998 & $\left(29^{\circ}-47,5^{\circ}\right)\left(29.5^{\circ}-48.5^{\circ}\right)$ & $38^{\circ}\left(38^{\circ}\right)$ \\
\hline Heinimann vd., 1998 & $\left(33^{\circ}-37^{\circ}\right)\left(33.5^{\circ}-38^{\circ}\right)$ & - \\
\hline Ayala-Carcedo vd., 2003 & $\left(29.1^{\circ}-38.9^{\circ}\right)$ & $\left(31.9^{\circ}\right)$ \\
\hline Jaboyedoff ve Labouise, 2003 & $32^{\circ}\left(33^{\circ}\right)$ & - \\
\hline Jaboyedoff ve Labouise, 2011 & $\left(32,6^{\circ}-35,6^{\circ}\right)$ & $34^{\circ}$ \\
\hline Corominas vd., 2003 & $\left(26^{\circ}-54^{\circ}\right)\left(27^{\circ} 55^{\circ}\right)$ & - \\
\hline Dorren ve Berger, 2005, 2006 & $31.3^{\circ}-37^{\circ}\left(31.9^{\circ}-38^{\circ}\right)$ & - \\
\hline Copons vd., 2009 (1.Aşama) & $\left(36.87^{\circ}-56.3^{\circ}\right)$ & - \\
\hline Copons vd., 2009 (2.Aşama) & $\left(28.81^{\circ}-42.0^{\circ}\right)$ & - \\
\hline Scheidegger, 1973 & $\left(29.68^{\circ}-39,69^{\circ}\right)$ & - \\
\hline Marquinez vd., 2003 (1.Aşama) & $\left(32.5^{\circ}-40.9^{\circ}\right)$ & $\left(31.5^{\circ}-40.2^{\circ}\right)$ \\
\hline Marquinez vd., 2003 (2.Aşama) & $\left(29.4^{\circ}-38.5^{\circ}\right)$ & $\left(31.5^{\circ}-40.2^{\circ}\right)$ \\
\hline Deparis vd., 2008 & $\left(31,61^{\circ}-47,20^{\circ}\right)$ & - \\
\hline Hyndman ve Hyndman, 2008 & $\left(33^{\circ}\right)$ & - \\
\hline Berger vd., 2009 (orman) & $\left(27.67^{\circ}-33.88^{\circ}\right)$ & - \\
\hline Berger vd., 2009 (orman hariç) & $\left(31.32^{\circ}-37.86^{\circ}\right)$ & - \\
\hline Berger vd., 2009 & $\left(32.57^{\circ}-48.99^{\circ}\right)$ & - \\
\hline
\end{tabular}

Kaya düşmesi deterministik analizlerinde menzil mesafesinin yanı sıra, yörünge boyunca kaya bloğunun hızı, kinetik enerjisi ve sıçrama yüksekliği gibi özellikle önleme yapılarının seçilmesi ve tasarlanmasında kullanılan diğer çıktılarda elde edilebilmektedir. Enerji Çizgisi Açısı kavramının kullanılması durumunda da belirli kabullerle bu değerlere ilişkin çıtıtır elde edilebilmektedir.
Kaynak noktasından durma noktasına kadar yatay mesafenin herhangi bir noktasında enerji çizgisiyle yamaç profili arasındaki kot farkı (Dh) kullanılarak, enerjinin korunumu gereği ve potansiyel enerjinin kinetik enerjiye dönüşümü ilkesi dikkate alınarak kaya bloğunun hızı da hesaplanabilmektedir. $\mathrm{Bu}$ değerlendirmenin geometrik girdileri ve eşitlikleri Şekil 5'te görülmektedir. 


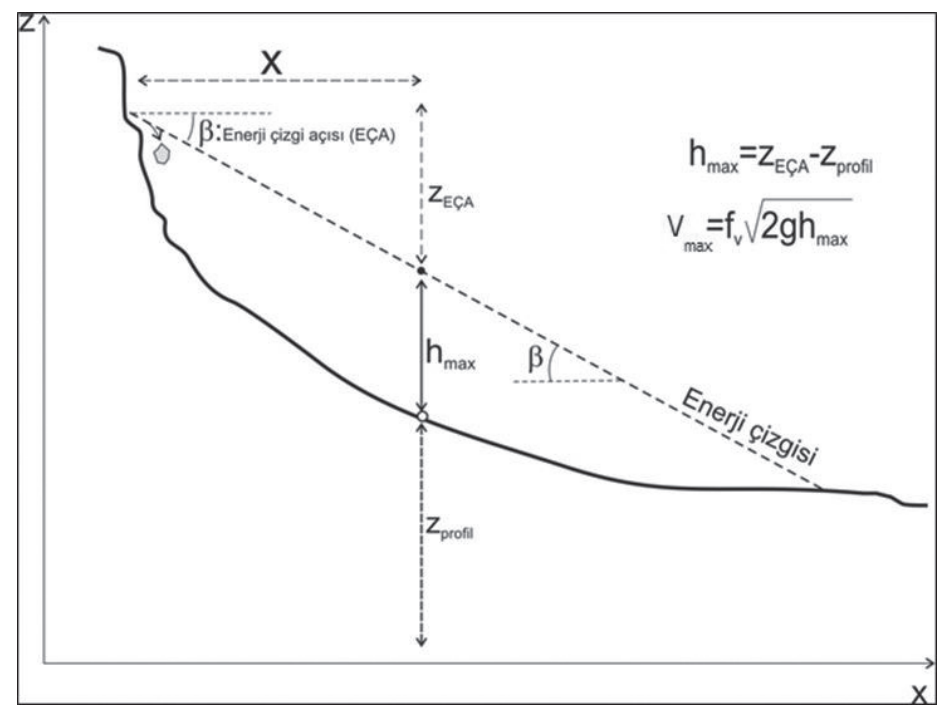

Şekil 5. Kaya bloğunun hızının enerji çizgi açısı ve yamaç profiline bağlı olarak hesaplanması (Larcher vd., 2012).

Figure 5. Calculation of rock block velocity based on energy line angle and slope profile (Larcher et al., 2012).

Kaya bloğunun hızının hesaplanmasında eşitlikteki $f_{v}$ hız için bir düzeltme veya kayıp faktörü olup, kaya bloğunun havadaki dönel hareketine ve sürtünmesine bağlı olarak düşen bloğun kinetik enerjideki kaybının \%20 kabul edilmesi durumunda $\mathrm{f}_{\mathrm{v}}=0.9(=0.8)$ alınmasinin uygun olacağ1 (Gerber, 1994; Jaboyedoff ve Labiouse, 2003; 2011) gibi araştırmacılar tarafından belirtilmektedir. Kot farkının en büyük olduğu durumda $\left(\mathrm{Dh}_{\max }\right)$ ise kaya bloğunun en yüksek hızı hesaplanmış olur. Düşen kaya bloğunun kütlesinin bilinmesi durumunda ise hız (v) ve kütleye (m) bağlı olarak kinetik enerjisi $\left(\mathrm{E}_{\mathrm{k}}=0.5 \mathrm{mv}^{2}\right)$ de hesaplanabilmektedir. Kaya düşmesi protansiyeli bulunan sahalarda hız ve kinetik enerji haritaları seçilen blok kütlesi ve en büyük veya belirli bir menzil mesafesi için konik yayılım yaklaşımıyla da hazırlanabilir.

\section{KARGABEDİR TEPE SAHA ÇALIŞMALARI}

Çalışma kapsamında inceleme alanı olarak seçilen Kargabedir Tepe 3946'08.59" ile 3946'25.48" kuzey enlemleri, 32²9'42.34" ile 32²9'54.29" doğu boylamları arasında yer almaktadır (Şekil 6). Ankara ilinin Yenimahalle ilçesine bağlı Balkuyumcu Köyü sinırları içinde kalan Kargabedir Tepe güneybatısında Alagöz, kuzeybatısında ise Alc1 Köyleri tarafından çevrelenmektedir. Yaklaşık 950 metre yüksekliğindeki bu tepe volkanik aktivite ile oluşmuş ve bölgedeki Jura yaşlı kireçtaşlarını keserek yükselmiştir. 


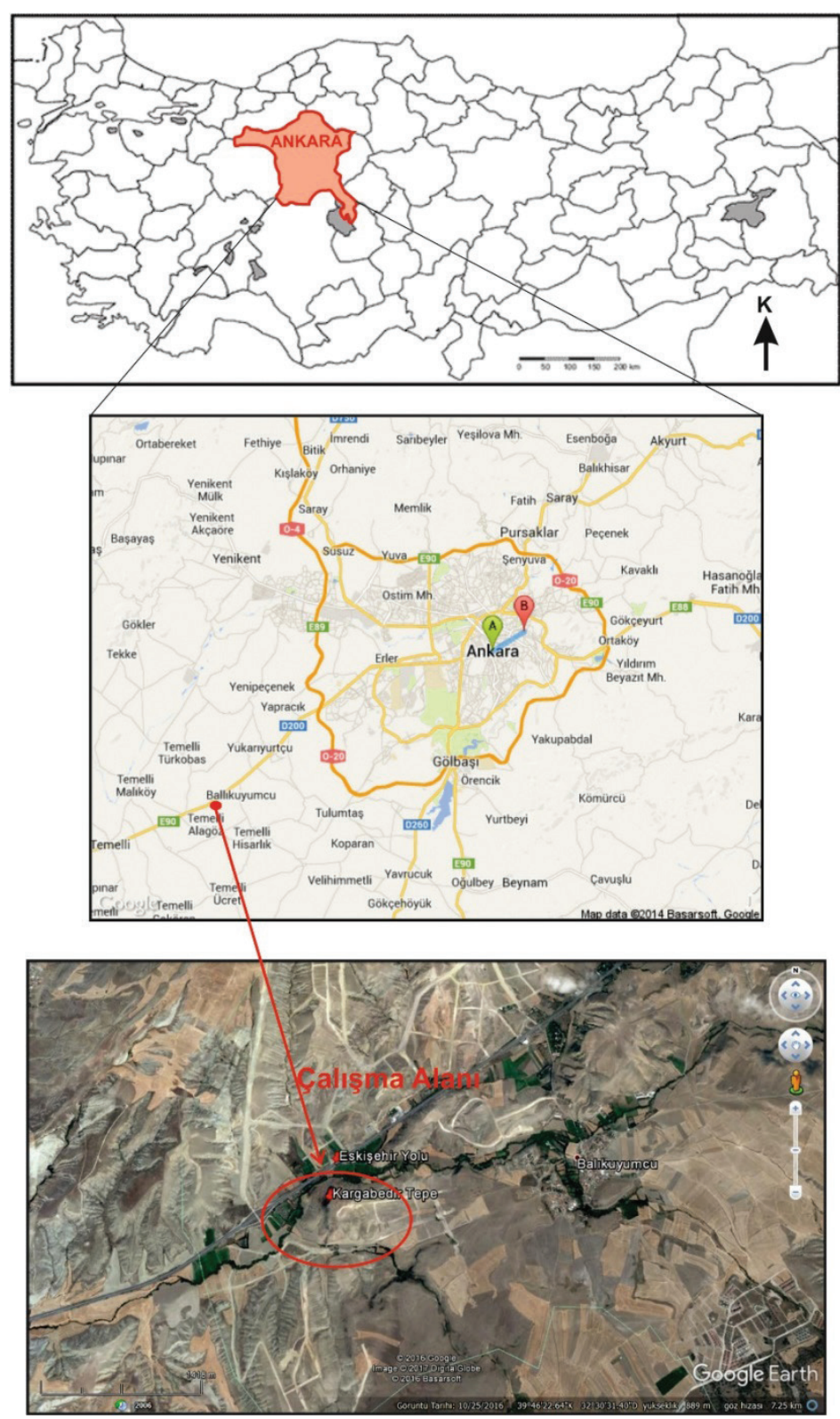

Şekil 6. Kargabedir Tepe yer bulduru haritası.

Figure 6. Location map of Kargabedir Hill.

Kargabedir Tepe bölgesi volkanik bir kaya kütlesi olup, kaya blokları birbirine yaklaşık dik konumlu süreksizliklerle sınırlandırılmış dörtgen şekilli bloklardan oluşmaktadır (Şekil 7). Saha çalışmaları kapsamında, Kargabedir Tepe'de kaynak bölgeden düşmüş kaya bloklarının koordinatları ve geometrileri de dikkate alınarak üç eksende boyutsal bilgi sağlanması amaciyla en uzun (boy), en kısa (en) ve "yükseklik" boyutları ölçülerek veri formlarına kaydedilmiştir. Düşen 
kaya bloklarının ölçümlenmesinde olabildiğince sahadaki genel yayılımı da yansıtacak şekilde çok sayıda örnekleme yapılmasına özen gösterilmiştir. Ayrıca, kaya düşmesi olayının üzerinde geliştiği yamaç aşağ 1 yüzeyin özellikleri de tanımlanmıştır.

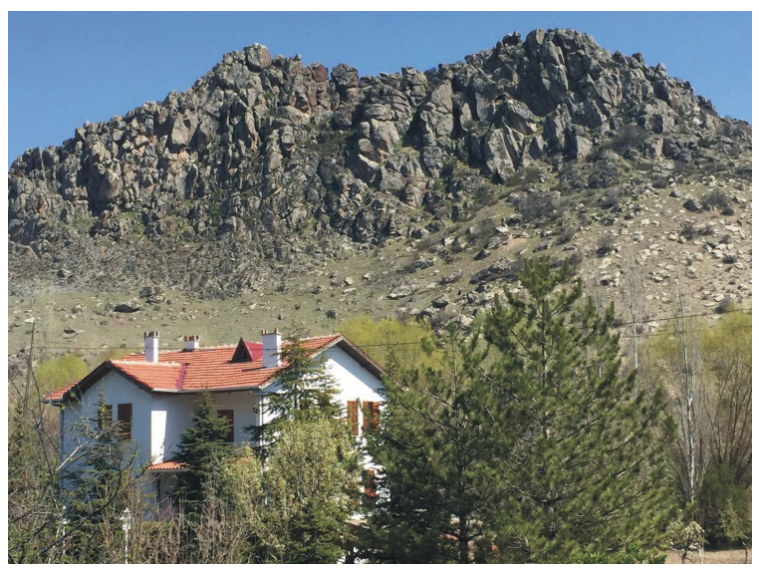

Şekil 7. Kargabedir Tepe sahasındaki bloklu yapıdaki kaya kütlesi.

Figure 7. Rock masses in Kargabedir Hill rockfall area.

\section{IHA Görüntüleri ile Sayısal Yükseklik Modeli ve Ortorektifiye Fotoğraf Görüntülerinin Oluşturulması}

Son y1llardaki gelişmelerle birlikte, havadan çok sayıda bindirmeli yüksek çözünürlüklü fotoğraflardan uygun bir yazılımla ortorektifiye fotoğraf görüntüleri hazırlanarak sayısal yükseklik modelinin oluşturulması tekniği Kargabedir Tepe kaya düşmesi bölgesinde uygulanmıştır. Ayrıca bu yüksek çözünürlüklü üç boyutlu görüntü modelinde düşen kaya bloklarına ilişkin konumlama ve boyutlama işlemleri de yapılmıştır. Hızlı bir şekilde yükssek ayrıntıda üç boyutlu modelinin elde edilmesinin yanı sıra, sahada erişilmesi güç veya olanaksız yerlerinde görüntüler üzerinden çalışılabilmesi İHA görüntülerinin kullanımı açısıdan önemli bir avantaj olarak değerlendirilmelidir.

Kargabedir Tepe'deki saha çalışmaları kapsamında inceleme alanlarının yüksek çözünürlüklü sayısal yükseklik modellerinin elde edilmesi amaciyla Ulusoy vd. (2017) tarafindan "Hareketten Yapı-Çok Bakı1ı Stereofotogrametri (HY-ÇBS)" yöntemi olarak isimlendirilen sayısal modelleme tekniği kullanılmıştır. $\mathrm{Bu}$ amaçla 4 pervaneli bir DJI Phantom3 Drone kullanılarak bölgenin yüksek çözünürlüklü hava fotoğrafları alınmıştır. Çalışma alanının SAM'nin oluşturulması amaciyla Kargabedir Tepe'nin zirvesinden $(950 \mathrm{~m}) 3.61 \mathrm{~mm}$ odak uzunluklu bir kameraya sahip 4 pervaneli hafif bir dron uçurulmuştur. Dron kamerasına bağlı 3 eksenli bir gimbal sayesinde uçuşlar sırasında meydana gelecek sarsintıları önlenmekte ve böylece yüksek çözünürlüklü hava fotoğrafları kolaylıkla alınabilmektedir. Uçuşlar zirveden itibaren 70 metre yükseklikten (yerel kot yaklaşık 1020 m) gerçekleştirilmiş ve Kargabedir Tepe'yi de içine alan $0.703 \mathrm{~km}^{2}$ 'lik alanın hava fotoğrafları alınmıştır. Dron 3 defa havalandırılmış ve 0.703 $\mathrm{km}^{2}$ 'lik alandan 12 megapiksel çözünürlüklü toplam 695 adet fotoğraf elde edilmiştir (Şekil 8). 


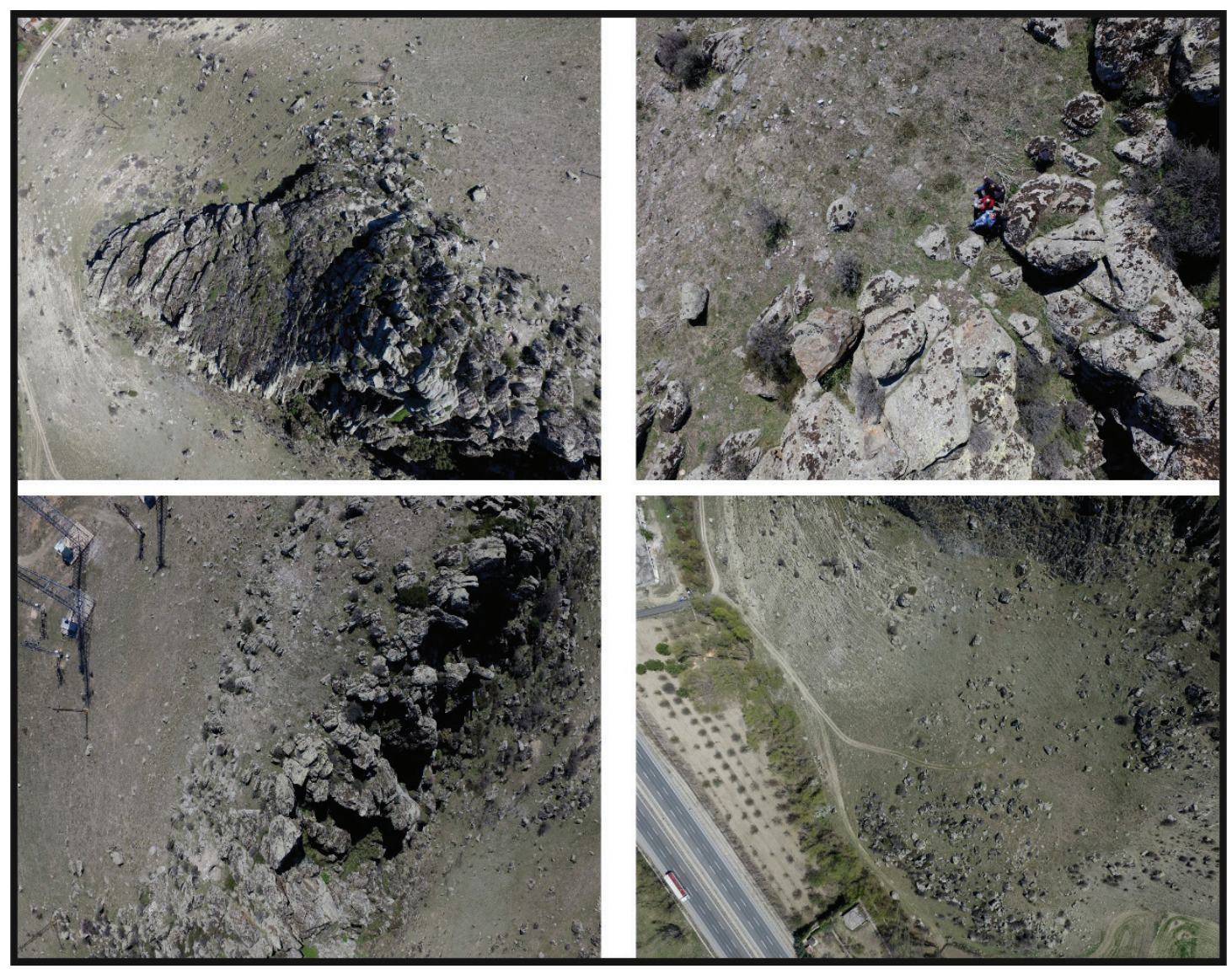

Şekil 8. Kargabedir Tepe'nin dron ile çekilen 12 megapiksellik hava fotoğrafları.

Figure 8. 12 megapixel aerial photographs of Kargabedir Hill taken by drone.

Şekil 9'da örnekleri verilen fotoğraflardan üst üste bindirmeli olanlar ayıklanmış ve 695 fotoğrafin 343 adedi kullanılarak Agisoft PhotoScan isimli bilgisayar programı yardımıyla görüntüsü alınan bölgeye ait 40x40 cm çözünürlüğe sahip bir sayısal yükseklik modeli ve $5 \times 5 \mathrm{~cm}$ çözünürlüklü ortorektifiye hava fotoğrafi oluşturulmuştur. Hava fotoğraflarının alındığı noktalar ve binili fotoğraf sayıları Şekil 9a'da görülmektedir. Uçuş fotoğraflama alanının 40x40 cm çözünürlüklü sayısal yükseklik modeli Şekil 10b'de, 5x5 cm çözünürlüklü ortorektifiye fotoğrafı, yakınlaştırılmış görüntüleri ve gerçek üç boyutlu görüntüsü Şekil 10'da verilmiştir. 
(a)

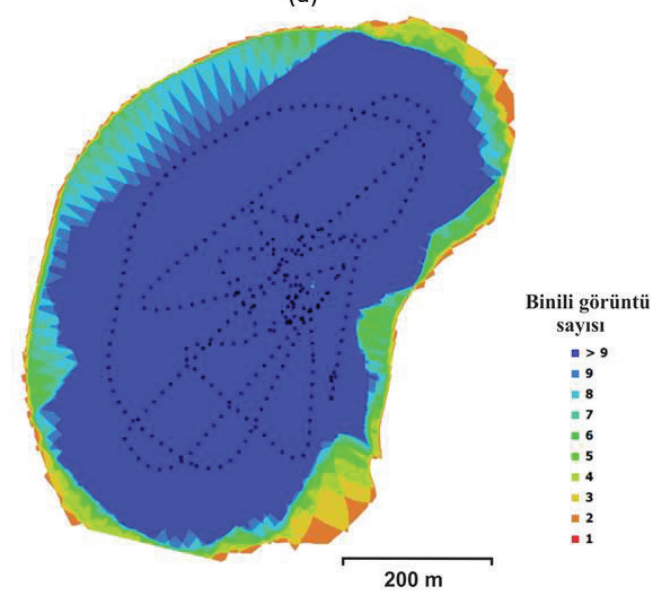

(b)

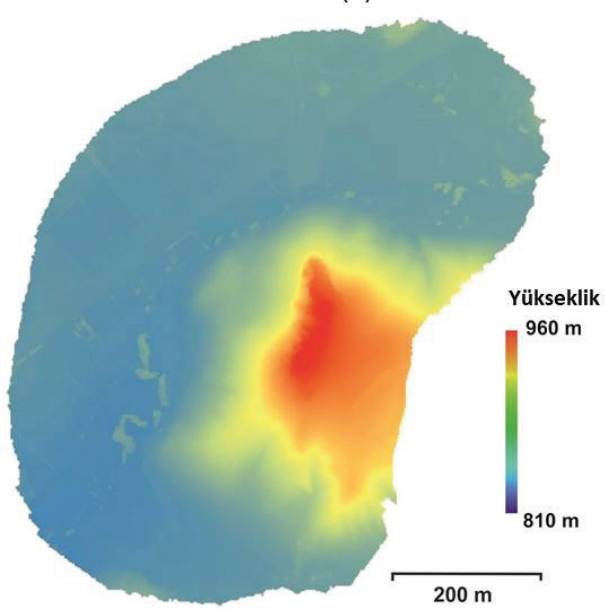

Şekil 9. (a) Hava fotoğraflarının alındığı noktaları ve bindirmeli görüntü sayısına sahip alanların dağılımı ve (b) 40x40 cm çözünürlüklü sayısal yükseklik modeli (SYM).

Figure 9. (a) Camera locations and image overlap (b) resolution of $40 \mathrm{~cm} /$ pixel digital elevation model (DEM).

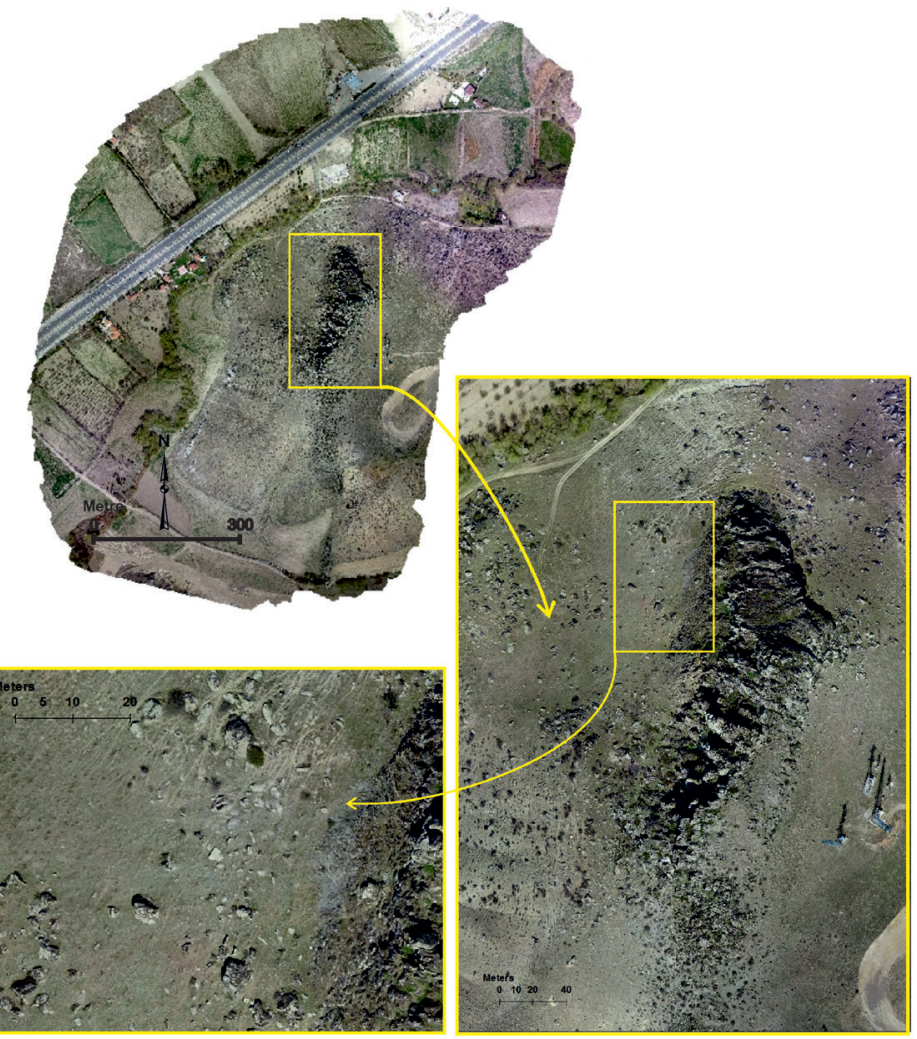

Şekil 10. Çalışma alanının 5x5 cm çözünürlüklü ortorektifiye fotoğrafi ve yakınlaştırılmış görüntüleri.

Figure 10. Resolution of $5 \mathrm{~cm} /$ pixel orthorectified aerial image and zoomed images of the field. 


\section{Düşen Kaya Bloklarının Konumlandırılması ve Boyutlandırılmast}

Kargabedir Tepe'de kaynak alandaki yüzeylenen kaya bloklarından sonra yamaç molozu (talus) ile örtülmüş ve üzerinde düşen ve özellikle birikme zonunda yarı gömülü büyük kaya bloklarının bulunduğu bir yüzey özelliği görülmektedir (Şekil 11). Moloz olarak tanımlanan malzemede toprak olarak tanımlanabilecek ince taneli malzemenin içerisinde farklı boyutlarda kaya parçalarının ve bloklarının bulunduğu görülmektedir. Kaynak alana yakın kısımlarda doğal olarak moloz birikiminin ince olduğu ancak yamaç eteklerine doğru kalınlığın çok fazla olduğu görülmektedir. Yamaç yüzeyi genellikle düz olup, daha önce düşmüş olan kaya blokları ve moloz içerisine yarı gömülü kaya blokları, düz yamaç yüzeyindeki çıkıntıları oluşturmaktadır (Şekil 12a).

Kaya düşmesi analizleri ve haritalamalarında düşmüş olan kaya blokların eğim aşağ1 yüzeydeki konumsal dağılımı sonuç haritalarının gerçekçiliğinin sınanmasının yanı sıra, boyutları da yayılım zonu içerisinde kaya bloklarının enerjisinin dağılımının hesaplanması açısından önem arz etmektedir. Bu nedenle, Kargabedir Tepe sahasında eğim aşağ1 yüzeydeki düşmüş kaya bloklarının konumları ve boyutları en, boy ve yükseklik olarak belirlenmiştir. $\mathrm{Bu}$ amaçla, sahada doğrudan konumsal ve boyutsal ölçümler en sağlıklı yaklaşım olmakla birlikte, sahada erişilmesi güç veya olanaksız kaya bloklarının ölçümesinin yanı sıra daha kolay ve hızlı konumsal ve boyutsal ölçüm yapılabilmesi nedeniyle sahaya ait İHA görüntülerinden elde edilen $5 \times 5 \mathrm{~cm}$ çözünürlüklü ortorektifye görüntü de bu amaçla kullanılmıştır (Şekil 12b). Özellikle kaya bloklarının sahadaki boyutlandırmasıyla İHA görüntülerinden elde edilen ortorektifiye görüntüye ait boyutlandırmaların karşılaştırmaları yapılmıştır. Ancak, bu görüntülerde derinlik verisi olmasına karşın kaya bloklarının "boy" ve "en” ölçümleri kadar gerçekçi "yükseklik" verisinin okunması mümkün olamamıştır. Diğer taraftan kaya bloklarının üzerinde durdukları yüzeye olan batma miktarlarının (kökleri) da ortorektifye görüntüden belirlenmesi veya buna ilişkin herhangi bir gözlem yapılabilmesi olanaklı değildir.

$\mathrm{Bu}$ çalışmada elde edilen Ortorektifiye görüntülerden yükseklik bilgisinin gerçekçi bir şekilde belirlenmesine yönelik sınırlamalardan dolay1, (i) yüksekliğin "h" en ve boyun ortalamasına " $h=(e n+b o y) / 2 "$, (ii) yüksekliğin "h" enine "h=en" ve (iii) yüksekliğin " $h$ " boyuna "h=boy" eşit kabul edildiği üç farklı yaklaşım ile ortorektifiye görüntüye ait değerlerle sahadaki ölçülen 55 verinin karşılaştırması yapılmıştır (Şekil 13).

Sahada şerit metreyle ölçülen 55 adet kaya kaya bloğunun "en", "boy" ve "yükseklik" boyutlarının oransal değerlerinin histogramları grafikleri ve genel istatistiksel değerlendirmeleri Şekil 14'de görülmektedir.

Kaya bloklarının sahada ölçülen "en", "boy" ve "yükseklik" boyutlarına ilişkin Şekil 14'deki değerlendirmelerden de görüleceği üzere Kargabedir Tepe'de yüzeylenen kaya bloklarının önemli düzeyde eş boyutlu oldukları görülmektedir. Ancak “en" ve "yükseklik" boyutlarının birbirlerine oransal değerinin ortalama $=1$ değeri etrafinda normal dağ 11 im sergilemesiyle birlikte "en" ve "yüksek"liğin "boy"a oranlanmasında genellikle oranın 0.5 'in üzerinde olduğu görülmektedir. $\mathrm{Bu}$ sonuçlarla kaya bloklarının önemli ölçüde eş boyutlu olmakla birlikte az da olsa kolonsal (iki boyutu birbirine eşit diğer boyutu daha uzun) şekle eğilimli olduğuna işaret ettiği söylenebilir. 

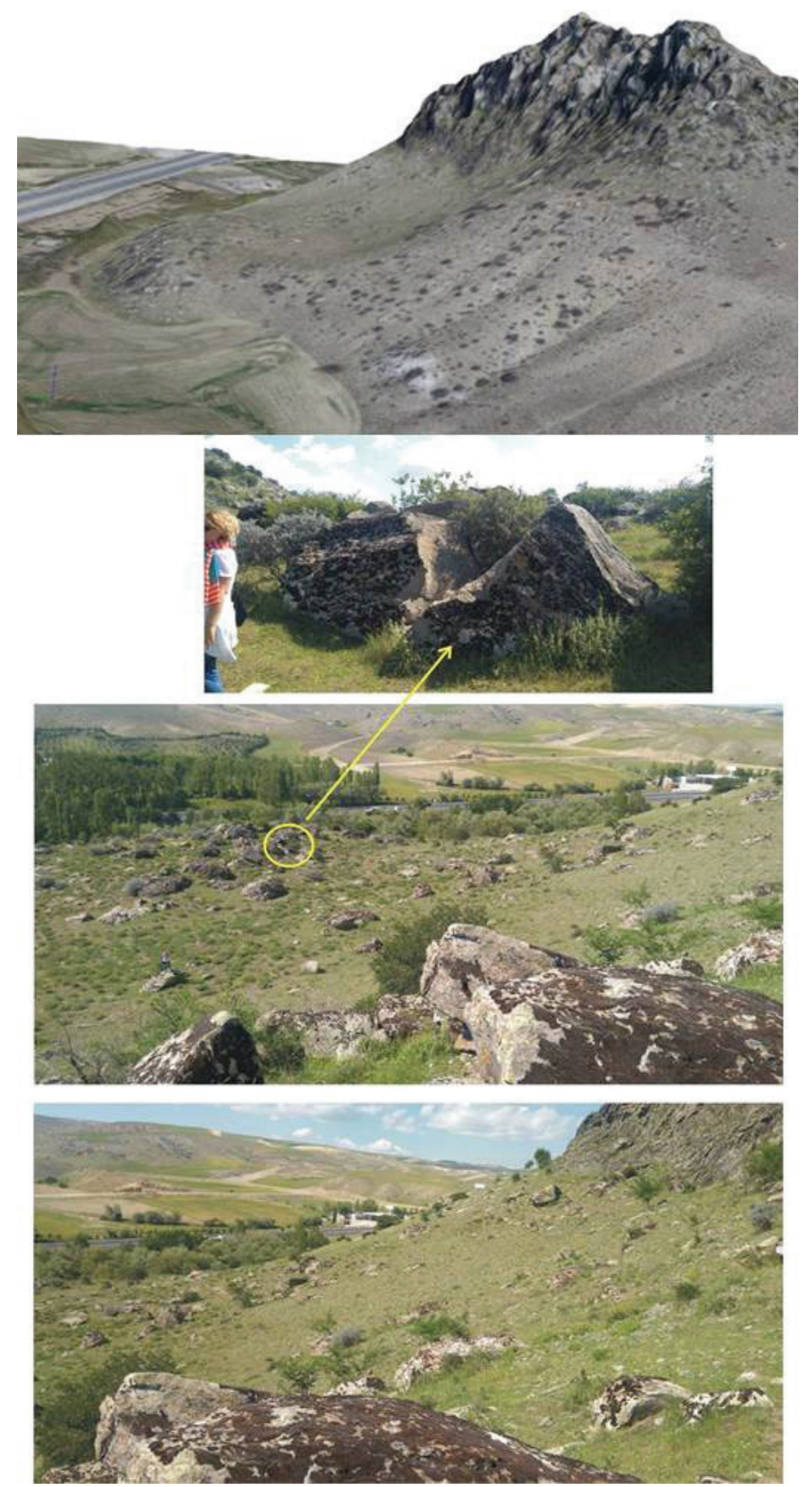

Şekil 11. Yamaç molozu örtülü yüzey, daha önce düşmüş yarı gömülü kaya blokları ve düşmüş kaya bloğuna çarparak kırılan büyük kaya bloğu.

Figure 11. Talus on the slope surface, previously fallen half-buried rock blocks and a large fragmented rock block that hit the fallen rock block. 
Araştırma Makalesi / Research Article

(a)

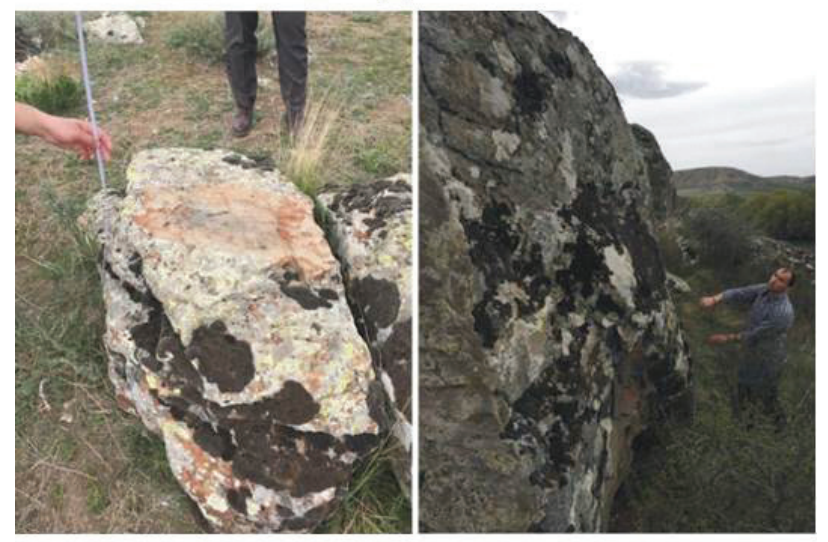

(b)

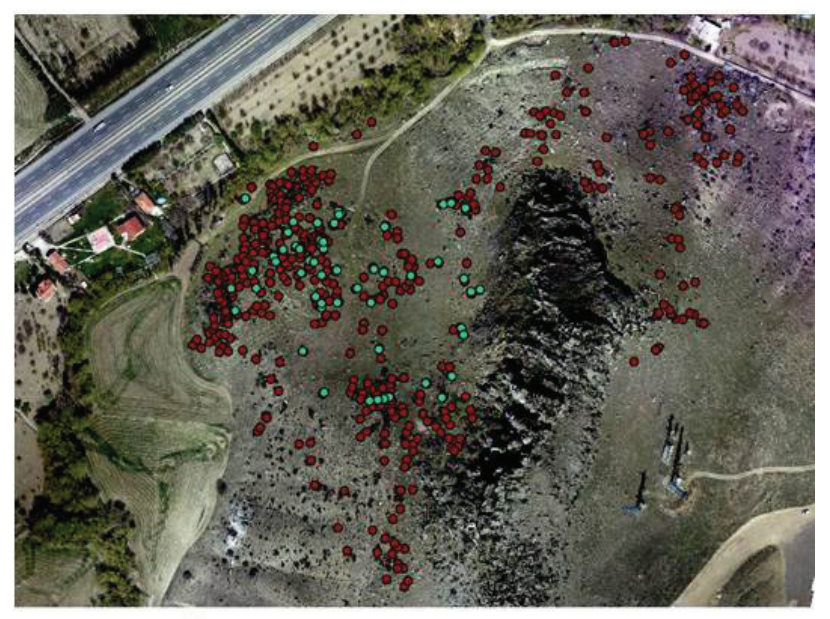

- ortorektifiye görüntüden ölçülen bloklar

- sahada ölçülen bloklar

Şekil 12. (a) Sahada blok boyutu ölçümlerinden görüntüler ve (b) sahada ve ortorektifiye hava görüntüsünden ölçülen kaya bloklarının konumsal dağılımı.

Figure 12. (a) Block size measurements on site and (b) positions of the blocks measured in the field and orthorectified image. 
(a)

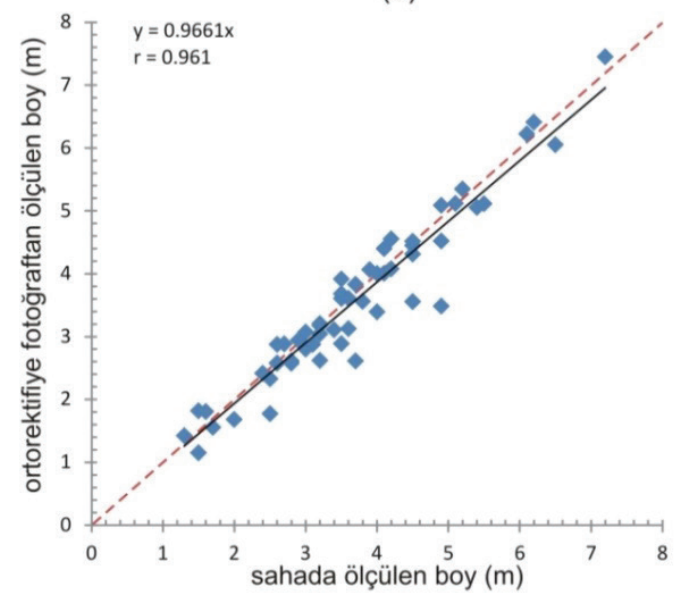

(c)

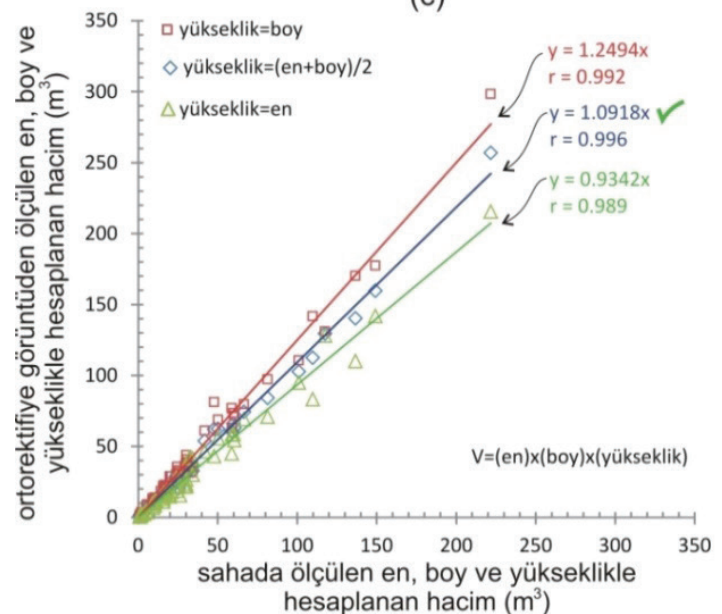

(b)

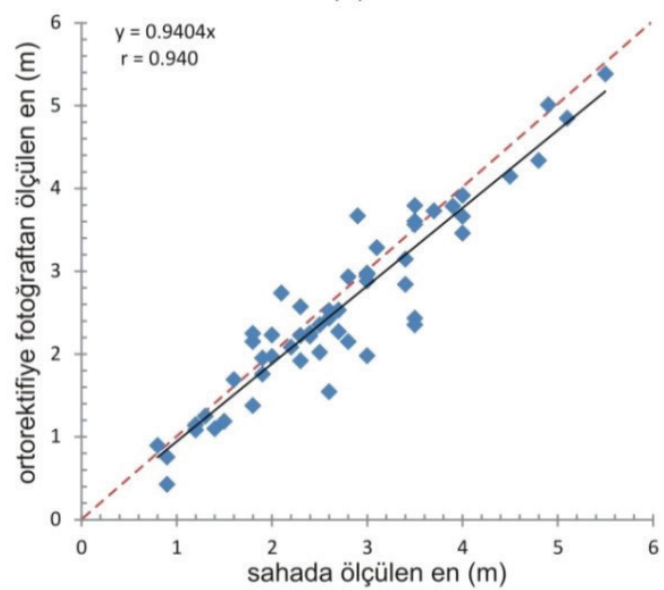

(d)

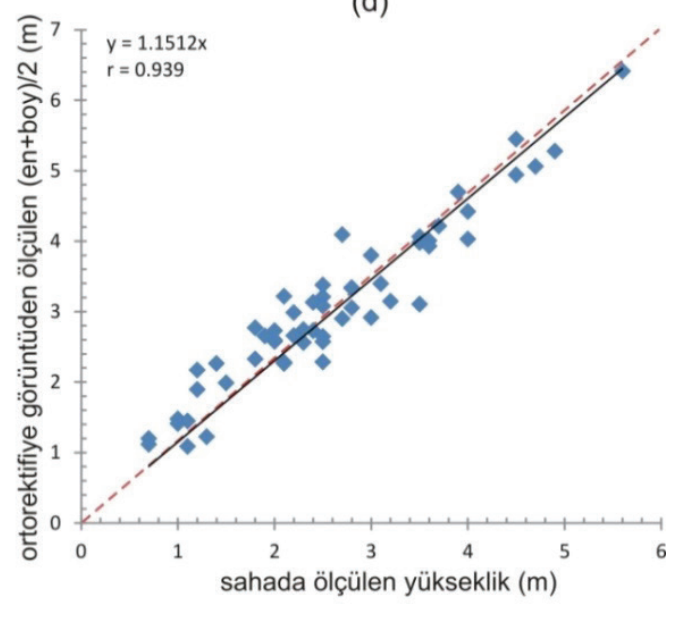

Şekil 13. Sahadan alınan (a) boy, (b) en verilerinin ortorektifiye görüntüden elde edilen verilerle karşılaştırılması, (c) blok hacmi hesaplanmasında yükseklik verileri için öngörülen farklı yaklaşımların karşılaştırılması, (d) sahada ölçülen yükseklikler ile yüksekliğin (boy+en)/2'ye eşit kabul edildiği durumun karşılaştırılması.

Figure 13. Comparison of (a) width and (b) length data obtained from the field; (c) comparison of the approaches for estimating the height of blocks to calculate the block volume and (d) comparison of the height data obtained from the field and the condition that the height is considered equal to (width + length) $/ 2$. 

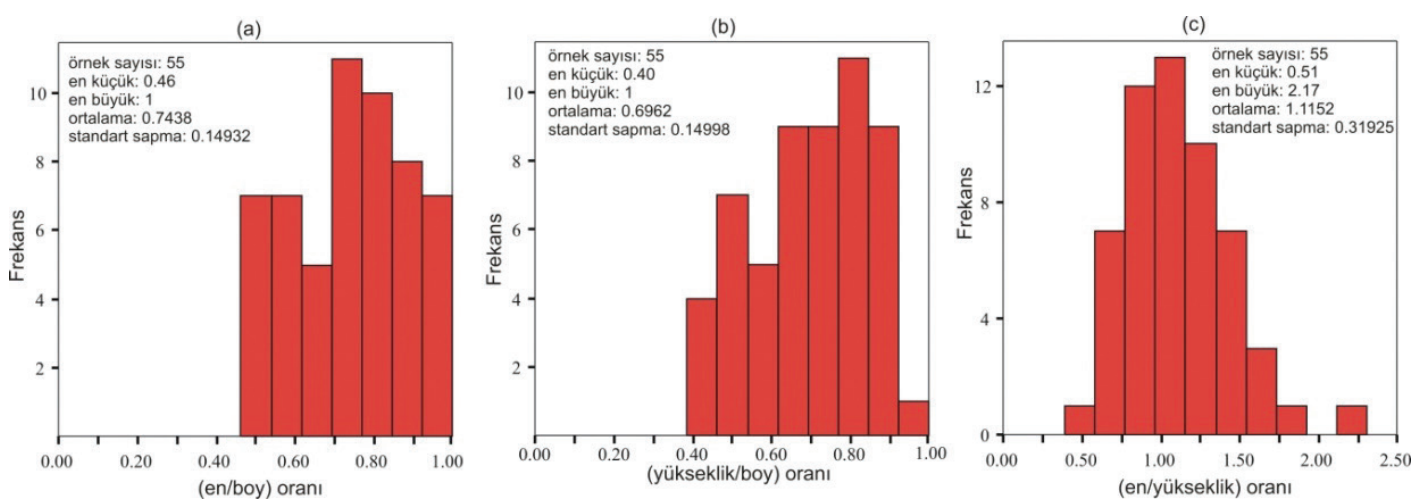

Şekil 14. Sahada ölçülen kaya bloklarının “en”, "boy” ve "yükseklik” boyutlarının oransal değerlerinin histogram grafikleri ve istatistiksel değerlendirmeleri.

Figure 14. Histograms and statistical evaluations of the "width", "length" and "height" values of the blocks measured on the field.

Ayrıca sahadaki kaya bloklarının mükemmel dörtgen şekilli olmadığı da diğer bir hatırlanması gereken durumdur. Pek tabi ki düşen kaya bloğu özelinde bloğun hacminin ve buna bağlı olarak kütlesinin (ağırlığının) çok daha gerekçi bulunmas1 daha yakın görüntülemeler vb. diğer gelişen teknolojik araçara bağlı olarak belirlenmesi mümkündür. Ancak, düşen kaya bloklarının hacimleri ve buna bağlı olarak kütleleri kaya düşmesi olayındaki yayılım zonundan ziyade tehlikenin bir bileșeni olup, dolayısıyla sahaya özel kaya düşmesi hacimel ve/veya kütlesel dağılımının belirlenmesi için ortorektifiye görüntüde yüksekliği en ile boy arasında bir değere sahip olacağı kabulu ile ortalamasının alınması yaklaşımının genel bir değerlendirme için yeterli olabileceği söylenebilir.

\begin{abstract}
Sahadaki 55 adet kaya bloğunun ortorektifiye görüntülerdeki ölçümleriyle karşılaştırılmasındaki yeterli düzeydeki uyum nedeniyle, ölçüm yapılan blok sayısının arttırılması amaciyla ortorektifiye fotoğraftan alınan kaya bloklarının konumları kullanılarak düşen kaya bloğu veri sayısı 463'e yükseltilmiştir. Ortorektifiye görüntüler üzerinde ArcGIS (v10.3) ortamında konum ve boyutlandırması yapılan düşen 463 kaya bloğunun “(yükseklik=en+boy)/2” yaklaşımı kullanılarak hesaplanan kaya bloğu hacim değerlerinin histogram dağılımı ise Şekil 15 'de görülmektedir. Kaya bloklarının hacimsel dağılımının süreksizlik aralığı için literatürde yaygın bir şekilde görülen negatif exponansiyel dağılıma benzer olduğu kaya bloğunun hacmindeki artışa bağlı olarak sahada görülme frekansının azaldığı görülmektedir.
\end{abstract}




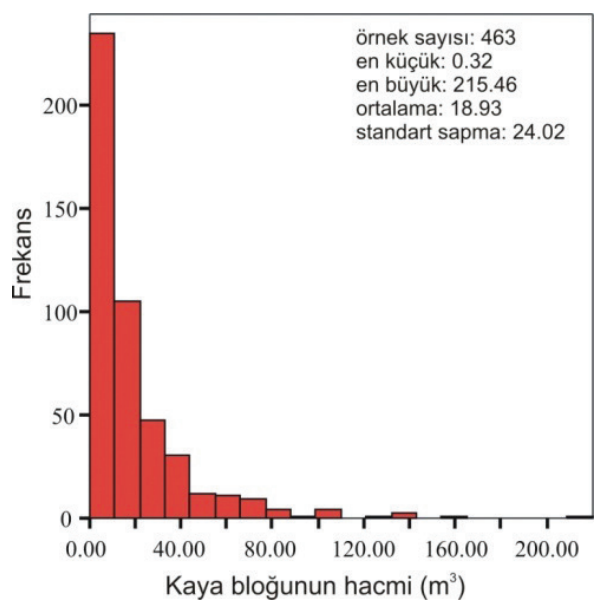

Şekil 15. Boyutları ortorektifiye görüntülerden ölçülen 463 adet düşmüş kaya bloğunun hacim dağılım histogramı.

Figure 15. Volume distribution histogram of the 463 fallen rock blocks of which the dimensions were measured from orthorectified image.

\section{KARGABEDİ TEPE KAYA DÜŞMESI BÖLGESİNDE KONIKK YAYILIM AÇISINA KARŞILIK KAYA BLOK DAĞILIMININ BELIRLENMESI}

Kargabedir Tepe ve yakın çevresinde $40 x 40 \mathrm{~cm}$ yüksek çözünürlüklü sayısal yükseklik modeli hazırlanmış olmasına karşın, konik yayılım açısı yaklaşımını dikkate alan CONEFALL programında 2x2m'lik çözünürlüğe kadar enerji hesaplamalarında çalışma hatası (runtime error) vermiştir. $\mathrm{Bu}$ nedenle, $2 \times 2$ m çözünürlüklü sayısal yükseklik modelinin kullanılması uygun görülmüştür. Kaynak alanların belirlenmesine yönelik sınır açısının belirlenmesi amacıyla eşitliği çözünürlük değeri $\mathrm{RES}=2 \mathrm{~m}$ için dikkate alınmış ve kaynak alanlar için sınır açı değeri $\alpha=52^{\circ}$ olarak belirlenmiştir. $\mathrm{Bu}$ değerin üzerindeki eğimler kaynak alan olarak ayırtlanmış ve sahadaki uyumluluğu ortorektifiye hava görüntüsündeki topoğrafya ile kontrol edilmiştir.

Kaynak alanlardan itibaren $20^{\circ}$ 'den başlayarak 45' ye kadar 5'er derecelik artışlara karşılık gelen enerji çizgi açısı değerleriyle CONEFALL programı çalıştırılmış ve yayılım zonları ortorektifiye görüntüsüne işlenmiştir (Şekil 16). Son olarak yayılım zonları içerisinde kalan blokların tüm bloklara yüzde oranları CBS ortamında belirlenerek enerji çizgi açısına karşılık blok dağılımı yüzde değerleri belirlenmiştir (Çizelge 2).

Çizelge 2. Kargabedir Tepe kaya düşmesi bölgesinde farklı konik yayılım açısı değerleri için belirlenen zonlar içerisindeki kaya bloklarının yüzde oranları ve duyarlılık sınıfları.

Table 2. Rock block percentage and susceptibility classes for different cone propagation angle values in Kargabedir Hill rockfall area.

\begin{tabular}{ccc}
\hline Konik yayılım açısı (Enerji çizgi açısı) & Kaya bloğu yüzde oranı & Duyarlılık sınıfı \\
\hline $20^{0}$ & $\% 100$ & Yok \\
$25^{0}$ & $\% 100$ & Çok düşük \\
$30^{\circ}$ & $\% 88.6$ & Düşük \\
$35^{\circ}$ & $\% 48.8$ & Orta \\
$40^{\circ}$ & $\% 34.3$ & Yüksek \\
$45^{\circ}$ & $\% 25.3$ & Çok Yüksek \\
\hline
\end{tabular}




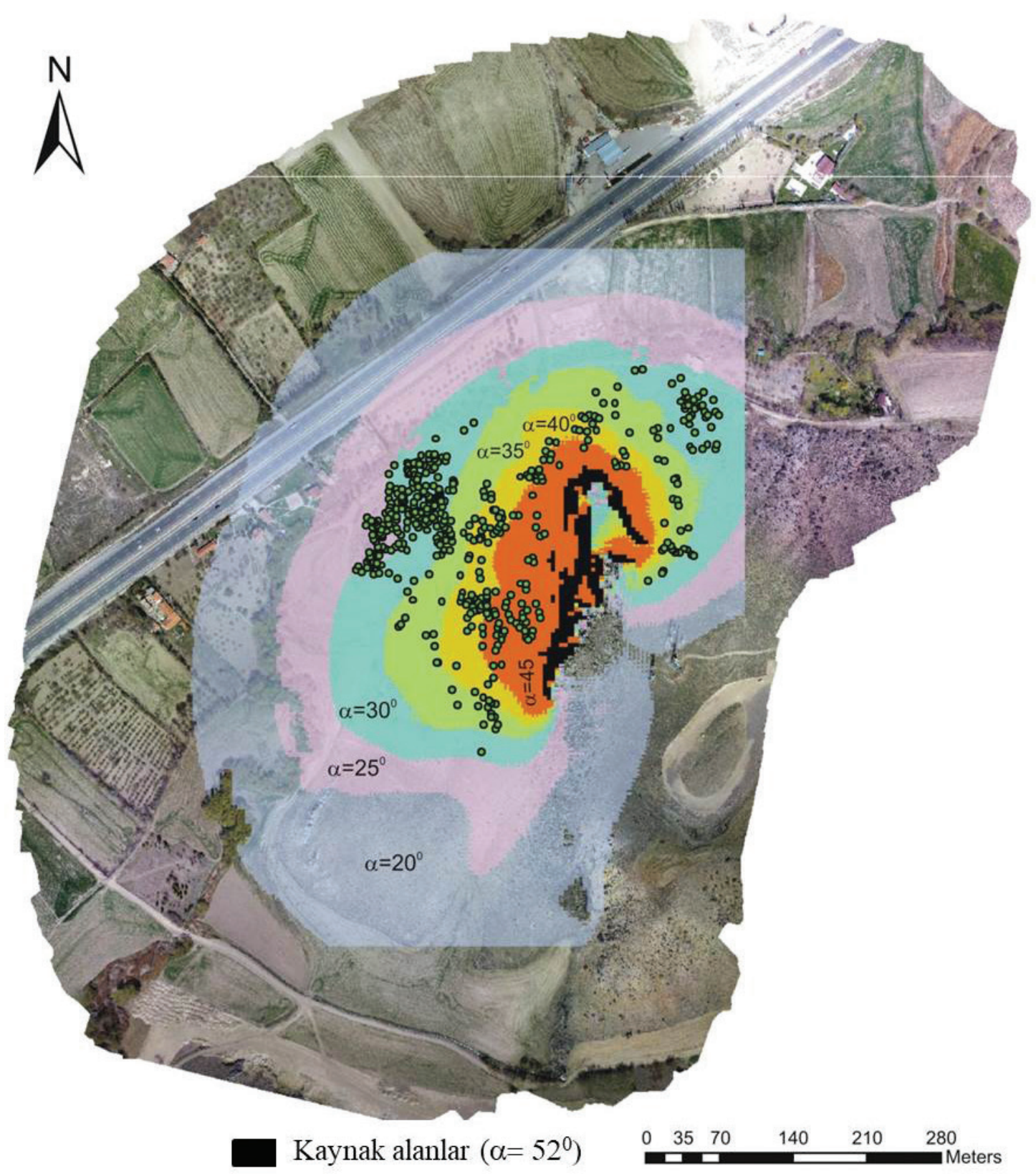

Şekil 16. Kargabedir Tepe kaya düşme bölgesindeki farklı enerji çizgi açısı değerleri için CONEFALL programıyla belirlenen yayılım zonları.

Figure 16. Propagation zones determined by CONEFALL program for different energy line angle values in Kargabedir Hill rockfall area. 


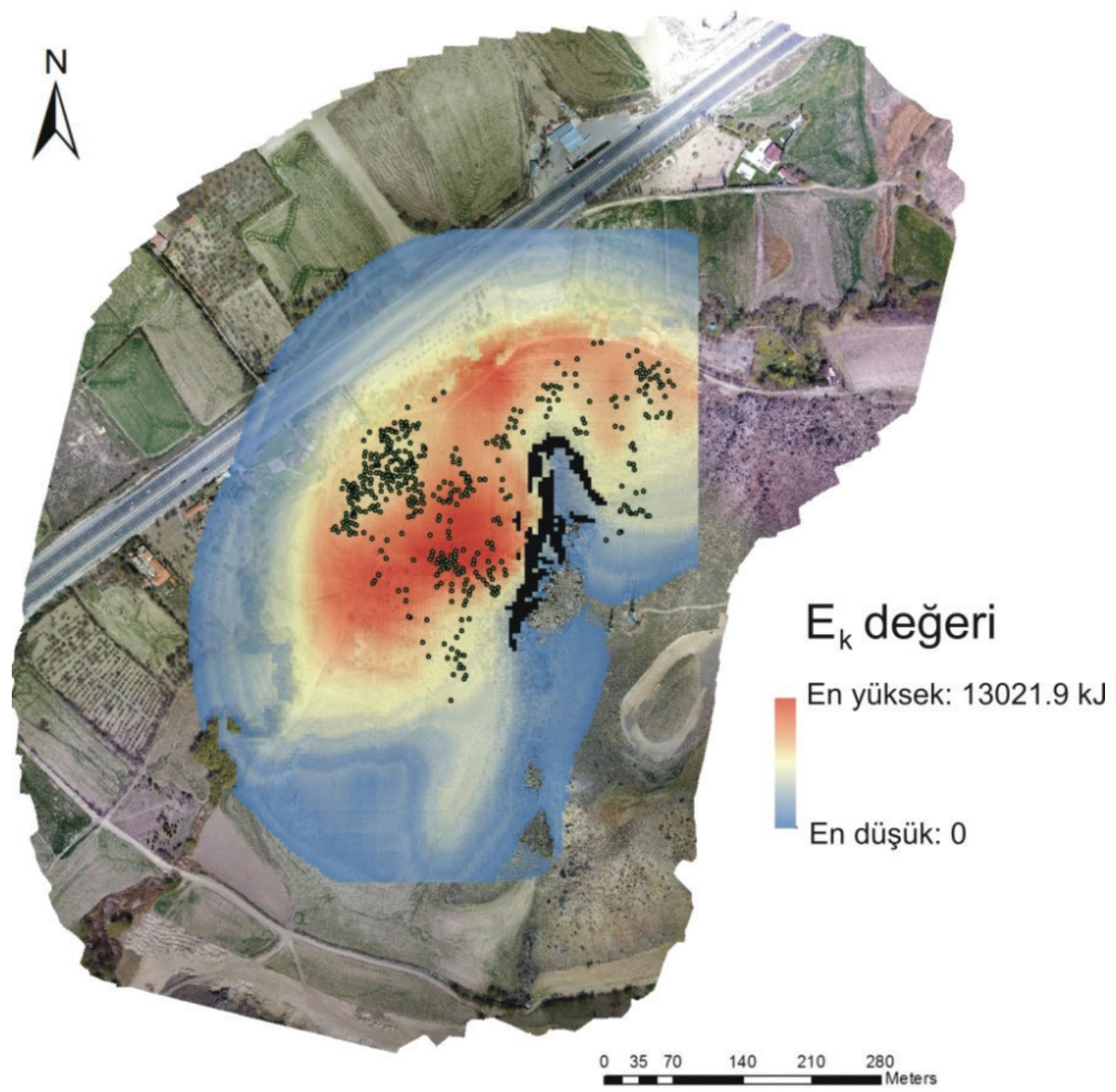

Şekil 17. Kargabedir Tepe kaya düşmesi sahasında kaya bloğunun kinetik enerji düzeyi $\left(\mathrm{E}_{\mathrm{k}}\right)$ haritası.

Figure 17. Kinetic energy level $\left(E_{k}\right)$ map of rock block at Kargabedir Hill rockfall area.

Buna ek olarak, çalışma sahası için en uzak yayılım noktalarını sınırlayan enerji çizgi açısı $\left(\mathrm{EÇA}_{\text {max stop }}=20^{\circ}\right)$ kullanılarak ve "Energies (kJ)" opsiyonuyla yine CONEFALL programı çalıştırılmış ve kaya bloğunun yayılım zonu içerisinde topoğrafyaya da bağlı olarak kinetik enerji düzeyi $\left(\mathrm{E}_{\mathrm{k}}\right)$ haritası üretilmiştir. Ortalama kaya blok hacmi V=18.93 $\mathrm{m}^{3}$ (bkz. Şekil 16) ve kaya malzemesi yoğunluğu $\rho=2.6 \mathrm{t} / \mathrm{m}^{3}$ kabul edilerek ortalama kaya bloğu kütlesi $M=49000$ $\mathrm{kg}$ (49 ton) olarak analizde dikkate alınmıştır. Her bir hücre (piksel) için kinetik enerji düzeyi tüm kaynak noktaları için hesaplanan değerlerin en büyüğü veya ortalaması şeklinde seçilebilmektedir. $\mathrm{Bu}$ çalışmada ortalama kinetik enerji değerleri için analizler yapılmıştır. 
Çalışma sahası için en geniş yayılım zonuna yönelik kinetik enerji düzeyi $\left(E_{k}\right)$ haritası Şekil 17'de verilmiştir.

Çalışma sahasında düşen kaya bloklarının hacimlerinin $0.32 \mathrm{~m}^{3}$ 'den $215.46 \mathrm{~m}^{3}$ 'e kadar değiştiği gözlemlenmiştir (bkz. Şekil 15). Ancak, kinetik enerji büyüklügü $\left(\mathrm{E}_{\mathrm{k}}=0.5 \mathrm{mv}^{2}\right)$ ilişkisinden de görüleceği üzere kütleyle doğru orantılı olup, Şekil 17'deki enerji haritasının 1 ton için 49 tona bölünerek normalize edilmesi mümkündür. Konik yayılım yaklaşımı ile hesaplanan enerji değerlerinin deterministik yaklaşımlardaki gibi topoğrafya üzerinde siçrama, sürüklenme ve yuvarlanma gibi hareketlere bağlı doğrudan hesaplanan hıza bağlı bir değer olmadığı dikkate alınarak, yayılım zonu içerisinde göreceli ve kaba bir değer olduğu göz önünde bulundurulmalıdır.

\section{SONUÇLAR}

Kaya düşmesi deterministik analizlerinde daha önce de belirtildiği gibi yamaç yüzeyine ve bloğa ait çok sayıda fiziksel ve mekanik parametre girdi olarak kullanılmaktadır. $\mathrm{Bu}$ nedenle özellikle ulaşılması güç ve geniş alanlarda yapılacak çalışmalarda bu tür verilerin elde edilmesi pek de mümkün olmamaktadır. $\mathrm{Bu}$ çalışmada bloklara ait sahadaki ölçümlerle yüksek çözünürlüklü ortorektifiye görüntüden elde edilen verilerin karşılaştırılmasındaki yeterli düzeydeki uyum nedeniyle veri sayıs1 arttırılabilmiş, sahada erişilmesi güç veya olanaksız kaya bloklarının ölçülmesinin yanı sıra daha kolay ve hızlı konumsal ve boyutsal ölçüm yapılabilmiştir.

Kaya düşmesi haritalamasında kaya bloklarının ulaşabilecekleri en uzak durma noktalarını hedefleyen yayılım zonu teorik olarak kaynak alandan düşen veya düşebilecek blokların \%100'ünü içermektedir. Geometrik olarak en uzak menzil mesafesi en düşük enerji açısına karşılık gelmektedir. Kaya düşmesinin gözlendiği bir sahada kaynak alandan eğim aşağ 1 en uzak durma noktasına kadar uzanan yayılım zonunda kaya düşmesinin farklı etkilenme yoğunluğuna (duyarlılığı) sahip zonların ayırtlanması mümkündür.

Çalışma kapsamında üretilen yayılım zonu haritasında $20^{\circ}$ lik enerji çizgi açısı için oluşturulan zon düşen 463 adet kaya bloğun tümü içermektedir. En uzak menzil mesafesini tanımlayan bu zonda kaya düşmesine karşı duyarlılığ1 "yok" olarak tanımlanmıştır. $\mathrm{Bu}$ bilgiler 1şığında bu çalışmada elde edilen enerji çizgi açısına karşılık yayılım zonunu gösteren haritada görüldüğü üzere kaynak alana yaklaştıkça kaya düşmesine karşı duyarlılık artmaktadır. Buna ek olarak, çalışma sahası için yine CONEFALL programı kullanılarak kaya bloğunun yayılım zonu içerisinde değişimini gösteren kinetik enerji haritası $\left(\mathrm{E}_{\mathrm{k}}\right)$ üretilmiştir. Bölgedeki ortalama kaya bloğu kütlesi $(\mathrm{M}=49000 \mathrm{~kg})$ için kinetik enerji düzeyinin en yüksek 13021.9 kJ olduğu görülmektedir.

$\mathrm{Bu}$ çalışmada uygulanan yöntem iki veya üç boyutlu kaya düşmesi deterministik analizlerin yerine kullanılması gibi yorumlanmamalı ve konik yayılım yönteminin daha ziyade bölgesel ölçekte kaya düşmesi haritalamalarında pratik bir yaklaşım olduğu dikkate alınmalıdır. $\mathrm{Bu}$ çalışmadaki tüm yaklaşımlar ampiriktir. $\mathrm{Bu}$ nedenle, her ampirik yöntemin doğasında olduğu gibi yeni sahalara ait verilerle birlikte değişime ve güncellemeye açı olduğu göz önünde bulundurulmalıdır.

\section{KATKI BELIRTME}

Saha çalışmaları sırasında kullanılan insansız hava aracının uçurulması ve görüntülerin 
işlenmesindeki destek ve yardımlarından dolayı Dr. İnan Ulusoy'a teşekkür ederiz.

\section{KAYNAKLAR}

Azzoni, A., de Freitas, M. H., 1995. Experimentally gained parameters, decisive for rock fall analysis. Rock Mechanics and Rock Engineering, 28, 2, 111-124.

Artuç, E. F., 2014. Susuz Köyü (Çubuk -Ankara) ve Yakın Çevresinin Kaya Düşme Potansiyelinin Araştırılması, Hacettepe Üniversitesi Fen Bilimleri Enstitüsü, Ankara, Yüksek Mühendislik Tezi, $92 \mathrm{~s}$ (yayımlanmamış).

Broili, L., 1973. In situ tests for the study of rockfall. Geol. Appl. idrogeol., 8, 105-111.

Bozzolo, D., Pamini, R., 1986. Modello matematico per lostudio della caduta dei massi. Laboratorio di FisicaTerrestre ICTS. Dipartimento Pubblica Educazione, Lugano-Trevano.

Copons, R., Vilaplana, J. M., Linares, R., 2009. Rockfall travel distance analysis by using empirical models (Solà d'Andorra la Vella, Central Pyrenees). Natural Hazards and Earth System Science, 9, 6, 2107-2118.

Corominas, J., 1996. The angle of reach as a mobility index for small and large landslides. Canadian Geotechnical Journal, 33, 260-271.

Chau, K.T., Wong, R.H.C., Lee, C. F., 1996. Rockfall Problems in Hong Kong and some new experimental results for coefficients of Restitution. International Journal of Rock Mechanics and Mining Sciences, 35, 4-5, 662663.

Derron, M.H., Stalsberg, K., Sletten, K., 2016. Method for the Susceptibility Mapping of Rock Falls in Norway. Technical Report, Trondheim, Norway.

Evans, S. G., Hungr, O., 1993. The assessment of rockfall hazard at the base of talus slopes. Canadian Geotechnical Journal, vol. 30, no. 4. pp. 620-636.

Gerber, W., 1994. Beurteilung des Prozesses Steinschlag. Birmensdorf: Herbstkurs Poschiavo, Kursunterlagen.
Heim, A., 1932. Der Bergsturz und Menschenleben. Fretz und Wasmuth Verlag, Zürich, 218 p.

Jaboyedoff, M., Labiouse, V., 2003. Preliminary assessment of rockfall hazard based on GIS data. Rock Mechanics, 575-578.

Jaboyedoff, M., Labiouse, V., 2011. Technical note: Preliminary estimation of rockfall runout zones. Natural Hazards and Earth Systems Science, 11, 3, 819-828.

Kalender, A., 2017. Konik yayılım yaklaşımıyla kaya düşmesi potansiyelinin değerlendirilmesine yönelik bir yöntem önerisi. Hacettepe Üniversitesi, Fen Bilimleri Enstitüsü, Ankara, Doktora tezi, $172 \mathrm{~s}$ (yayımlanmamış).

Larcher, V., Simoni, S., Pasquazzo, R., Strada, C., Zampedri, G., Berger, F., 2012. WP6 guidelines Rockfall and Forecast systems, Italy.

Ritchie, A. M., 1963. Evaluation of Rockfall and its Control. Stability of Rock Slope Vol 17, Highway Research Board, National Academy of SciencesNational Research Council, Washington, DC, $13-28$.

Troisi, C., Berger, F., Dorren, L., 2008. Protection de la viabilité alpine, PROVIALP project report.

Ulusoy, İ., Şen, E., Tuncer, A., Sönmez, H., Bayhan, H., 2017. 3D Multi-view Stereo Modelling of an Open Mine Pit Using a Lightweight UAV. Geology Bulletin of Turkey, 60, 223-241.

Varnes, D. J., 1978. Slope movements: types and processes. Transportation Research Board, Washington, DC: Special Report No. 176.

Volkwein, A., Schellenberg, K., Labiouse, V., Agliardi, F., Berger, F., Bourrier, F., Dorren, L. K. A., Gerber, W., Jaboyedoff, M., 2011. Rockfall characterisation and structural protection - A review, Natural Hazards and Earth Systems Sciences, 11, 9, 2617-2651.

Zhao, T., Crosta, G. B., Utili, S., De Blasio, F. V., 2017. Investigation of rock fragmentation during rockfalls and rock avalanches via 3-D discrete element analyses. J. Geophysical Res. Earth Surf., 122, 678- 695 . 